\title{
مستوى الإستفادة المعرفية للريفيات من متضمنات أنظمة شبكة إتصال التنمية الريفية والزراعية (رادكون) ببعض قرى محافظة البحيرة
}

\author{
أبو زيد محمد محمد الحبال و *جمال بخيث حسين عامر و سوزلن إبراهيم السيد الشريتلي \\ و *نان نجيب علي طحاوي \\ كلية الزراعة سابا باشا - جامعة الإسكندرية \\ "معهز بحوث الإرشاد الزراعي والنتمية الريفية - مركز البحوث الزراعية
}

الملخص : إستهدف هذا البحث التعرف على مستوى الإستفادة المعرفية للريفيات من متضمنات أنظمة شبكة إتصال التتمية الريفية والزراعية (رادكون) ببعض قرى محافظة البحيرة ، وإنحصرت وسائل تحقيق هذا الهدف في :

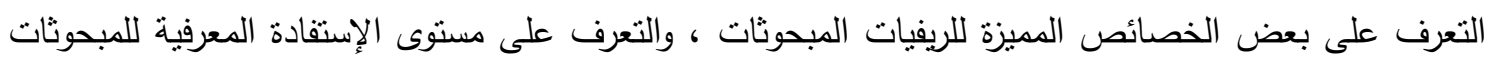

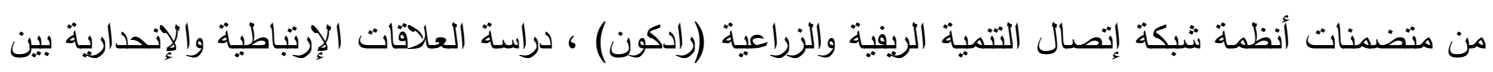
مستوى الإستفادة المعرفية للمبحوثات من منضمنات أنظمة شبكة إتصال التتمية الريفية والزراعية (رادكون) والمتغيرات المستقلة المدروسة ، والتعرف على المشكلات التي تواجه المبحوثات عند الإتصال بشبكة الإتصال

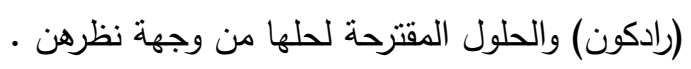

تمثلت شاملة البحث في جميع الريفيات اللآتي تعرضن لنبكة إتصال التنمية الريفية والزراعية (رادكون) ببعض مراكز محافظة البحيرة ، وقد ثم إستيفاء البيانات البحثية من 160 ريفية مبحوثة ، من خلال إستمارة

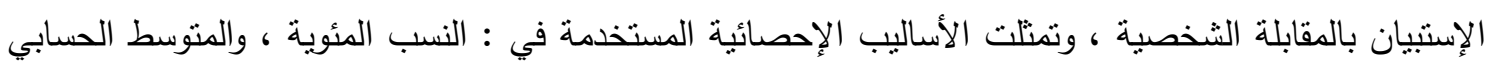

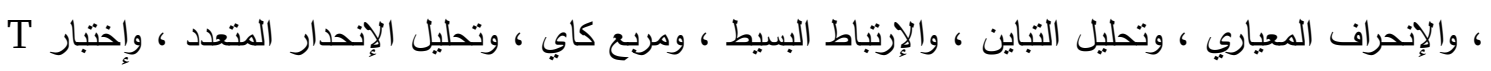

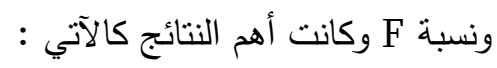

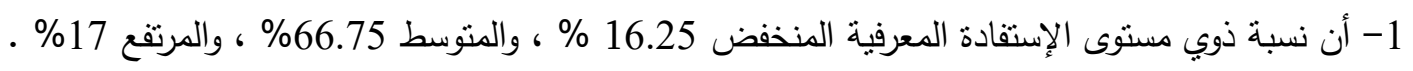
2- وجود علاقة إرتباطية موجبة وذات دلالة إحصائية بين مستوى الإستفادة المعرفية للريفيات من متضمنات

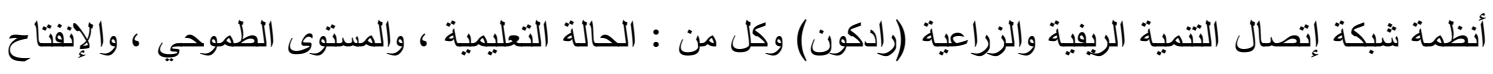

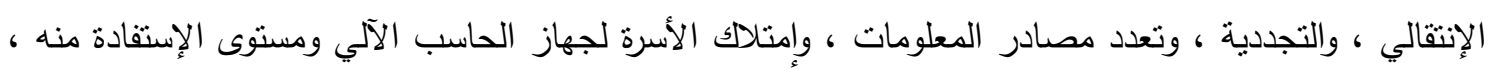
ومستوى التعرض للشبكة ، والمعرفة بأنظمة الثبكة ، والرضا عن الثبكة ، والمستوى التقييمي لخصائص محتوى ولثي الثبكة .

3- أن المتغيرات المستقلة الخمسة وهي : تعدد مصادر المعلومات ، و التجددية ، والمعرفة بأنظمة الثبكة ،

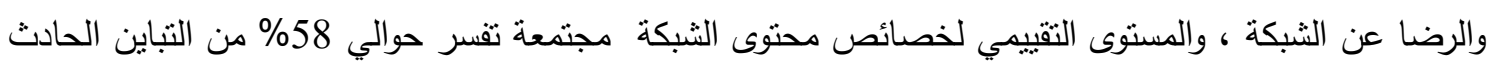

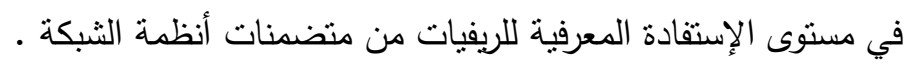

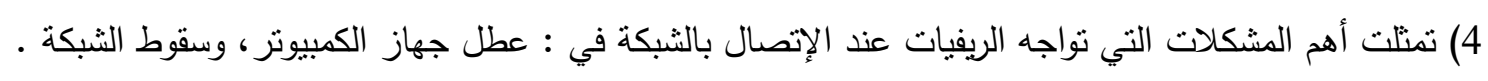
الكلمات الالالية : الإستفادة المعرفية - الإتصال - تكنولوجيا الإتصالات والمعلومات - شبكة إتصال التتمية

$$
\text { الريفية والزراعية (رادكون) : الإنهات }
$$




\section{المقدمة والمشكلة البحثية :}

تعد التتمية الريفية المتكاملة والمستدامة هي غاية المؤسسات التي تعمل في الريف ونشاط كل مؤسسة تتارك في القرية ، وهي أداة نساعد على تحقيق هذه التتمية وأن لكل مؤسسة نشاطها الذي يميز طبيعة إختصاصها وحدود مسئوليتها في عجلة التتمية ، وأن تقصير أي مؤسسة في القيام بالدور المحدد لها يعثبر نقطة ضعف وخلل في التتمية ولا تسنطيع أي مؤسسة أخرى القيام بهذا الدور لعدم إختصاصها ، وتوجد علاقة قوية بين

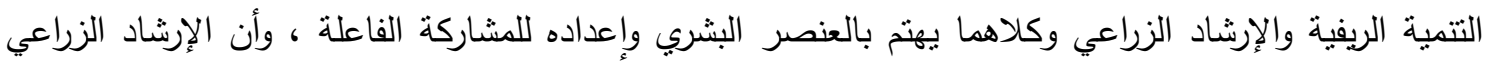

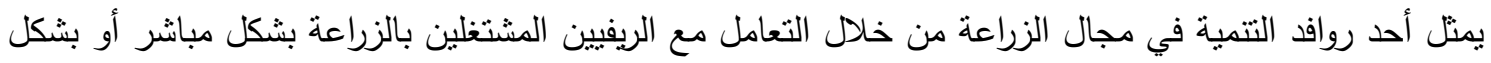

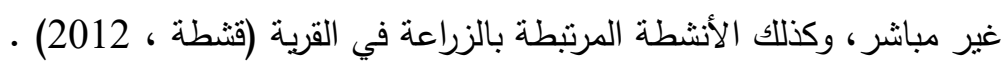
ولما كان العنصر البشري هو الأساس في نجاح برامج التتمية وأن الاستثمار الأمثل لدور المرأة التي تمثل

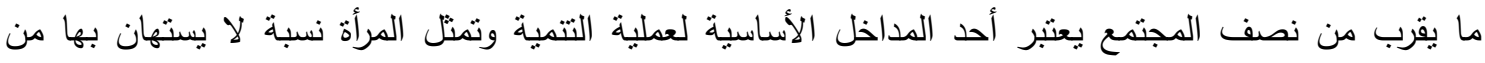

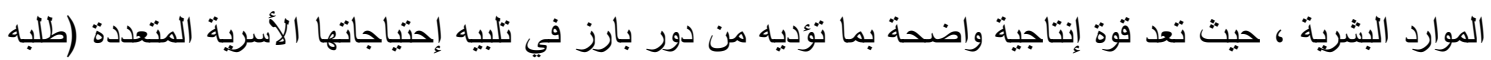
وآخرون ، 2001) ،ونجد أن الإرشاد الزراعي لا يقتصر دوره على الزراع بل يمتد هذا الدور إلى المرأة الريفية

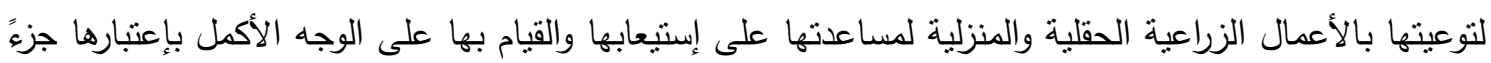

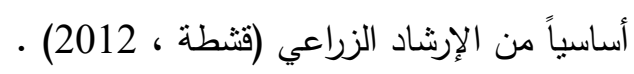
وتساعد تكنولوجيا المعلومات والإتصال في إستنفاء الإحتياجات وتحديث الخبرات التعليمية من خلال فتح

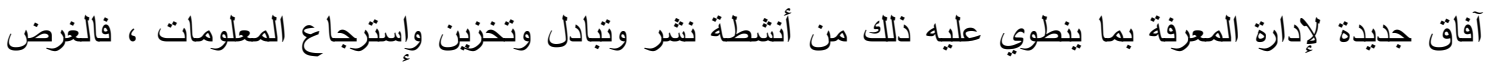

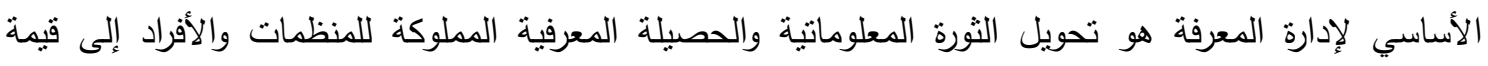
يتحقق الإستفادة منها بصورة مستمرة ، الأمر الذي يعمل على تقوية ودفع المنظمات نحو التقدم والإزدهار

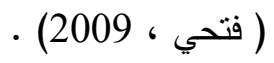

ومن هنا فإن الإستفادة بالتطورات السريعة والمتلاحقة في مجال الإتصال عن بعد وتكنولوجيا المعلومات

القائمة على إستخدام الحاسب الآلي والإنترنت يمكن أن تسهم في تطوير وتحديث العمل الإرشادي الزراعي ، فتكنولوجيا المعلومات سوف تقدم خدمات معلوماتية جديدة للمناطق الريفية نساعدهم على إتخاذ القرارات المزرعية

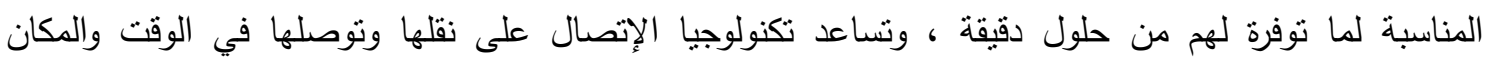
المناسبين وفي الإتجاه العكسي (البنداري ،2005) • وتعتبر شبكات الإتصال المعتمدة على الحاسب الآلي وسيلة يمكن من خلالها نشر المعلومات على وجه السرعة لعدد كبير من المستخدمين ، حيث يعتمد على إستخدام الربط

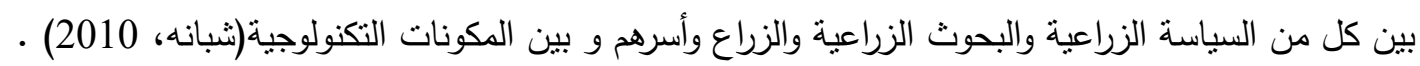

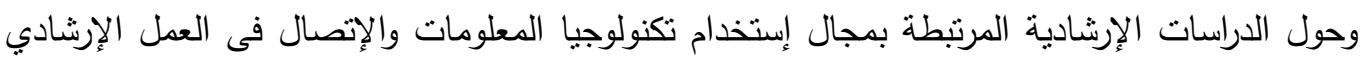

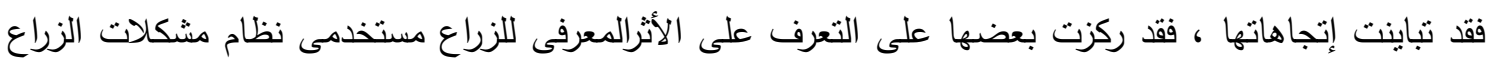

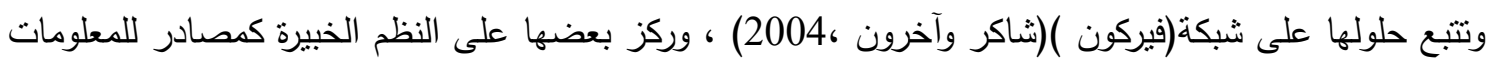

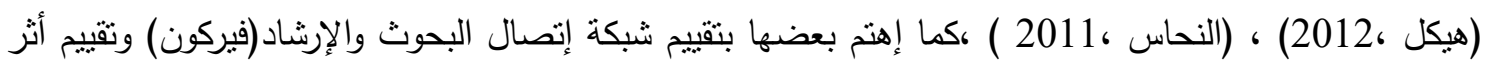

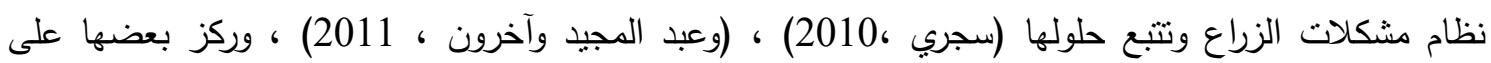

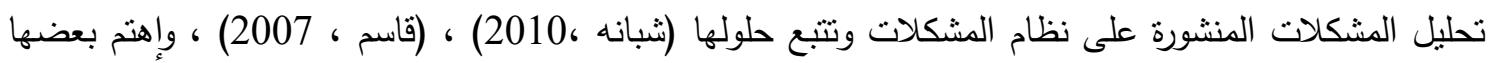
بدراسة الأثر المعرفي لإستخدام شبكة إتصال البحوث بالإرشاد (فيركون) ، (عبد الواحد وآخرون ، 2010) ، كما كأن ، 
ركز البعض الآخر على مضمون شبكة إتصال التتمية الريفية والزراعية (رادكون) (حسيب والبندارى،2010)، و (الذهبي والثافعي ، 2012) ، و (واكد والجزار ، 2012) .

ومن أهم تطبيقات إستخدام التكنولوجيا الحديثة فى العمل الزراعي والتي بدأ إستخدامها فى مصر عام عام

2000 كأول تطبيق لتكنولوجيا المعلومات والإتصالات فى المجال الإرشادي كانت شبكة إتصال البحوث بالإرشاد الزراعي (VERCON) مشروعات برنامج التعاون الفني لمنظمة الأغذية والزراعة للأمم المتحدة (FAO) (قاسم ، (2007) ل ولتحقيق الإستفادة من تكنولوجيا المعلومات والإتصال في القطاع الزراعي قامت وزارة الزراعة واستصلاح الأراضي بإنشاء العديد من مراكز المعلومات ووحدات الحاسب الآلي المتخصصة في المجالات الزراعية المختلفة البحنثة والإرشادية والخدمية والإدارية ، لخدمة أغراض العمل الزراعي وسرعة تدفق المعلومات وترشيد إنخاذ القرارات المزرعية المناسبة .

وفي هذا الإطار تباشر شبكة إتصال التتمية الريفية والزراعية (رادكون) عملها كسبيل لتتمية القطاع الريفي حيث تستهدف تتمية الأسر والمجتمعات الريفية وتلبية إحتياجاتهم من المعلومات والخبرات لتوفير فرص الترك الحياة الكريمة والحد من الفقر ، كما تمكن هذه الثبكة المجتمعات من المشاركة الإيجابية للتعرف على مشكلاتهم والإستجابة لها من خلال نوفير وسائل التواصل وتبادل المعلومات والخبرات من أجل خدمة مجنمعاتهم الريفية

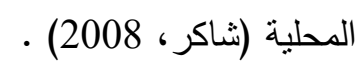

لذا فقد أولت الدولة عناية وإهتماماً بالأسرة والمرأة الريفية والإستفادة من التقام الهائل فى مجال تكنولوجيا المعلومات والإتصالات لتتميتها وتثقيفها وإثارة وعيها وإعدادها لتمكينها من القيام بأدوارها المختلفة سواءً المنزلية والأسرية والإنتاجية الزراعية و المجتمعية من أجل النهوض بالمستويات المعيشية للأسرة الريفية ، وذلك من خلال

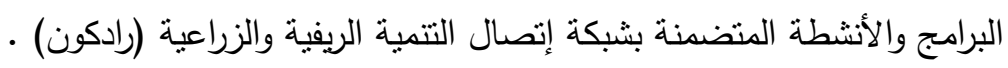

ونظراً لندرة الدراسات التي إهتمت بدراسة مدى الإستفادة المعرفية من شبكة إنصال التنمية الريفية

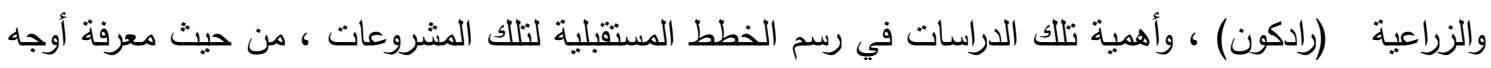
الإستفادة منها والقصور وأثارها على الريفيات لكي يمكن التركيز على أوجه هذه الإستفادة عند تطبيقها مستقبلاً في

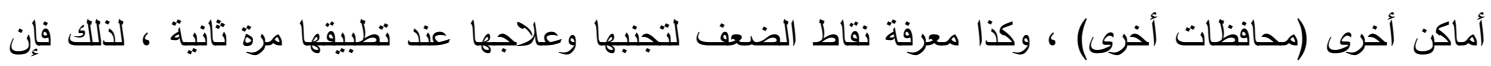
هذه الدراسة بصدد معرفة مستوى الإستفادة المعرفية للريفيات المبحوثات من متضمنات أنظمة شبكة إتصال التتمية

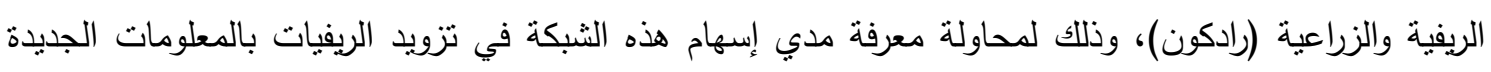

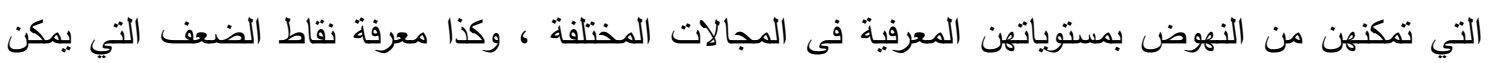
تجنبها عند التطبيق مرة ثانية مستقبلاً . الأهداف البحثية : تنتخص أهداف هذه الدراسة في : 1- التعرف على بعض الخصائص المميزة للريفيات المبحوثات . 2- التعرف على مستوى الإستفادة المعرفية للريفيات المبحوثات من متضمنات أنظمة شبكة إتصال التتمية الريفية لعنية • والزراعية (رادكون) 3- دراسة العلاقات الإرتباطية والإنحدارية بين مستوى الإستفادة المعرفية من متضمنات شبكة إتصال التتمية الريفية والزراعية (رادكون) والمتغيرات المستقلة المدروسة. 
4- التعرف على المشكلات التي نواجه الريفيات عند الإتصال بشبكة إتصال التتمية الريفية والزراعية (رادكون) والحلول المقترحة لها من وجهة نظرهن • الإطار النظري : (النظول

يسعى الإرشاد الزراعي بإعنباره عملية تعليمية إلى إحداث تغييرات سلوكية في جمهور الزراع محددة في

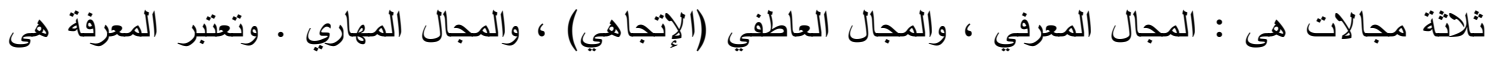

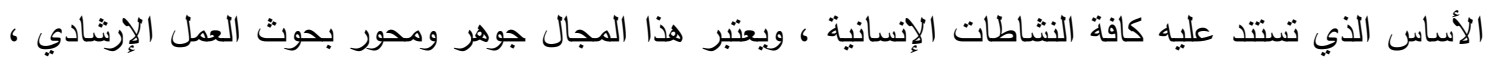

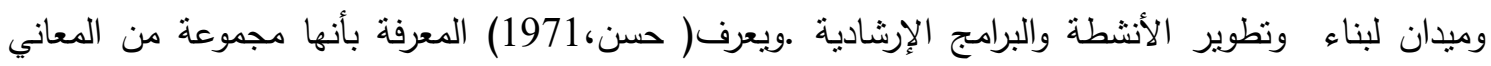
والمعتقدات والأحكام والمفاهيم والتصورات الفكرية التي تتكون لادى الإنسان نتيجة لمحاولاته المتكررة لفهم الظواهر والأشياء الدحيطة به.ويختلف البنيان المعرفي من فرد إلى آخر ، ويرجع هذا الإختلاف إلى تباين البيئة الطبيعية

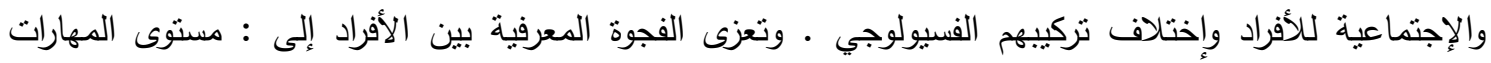

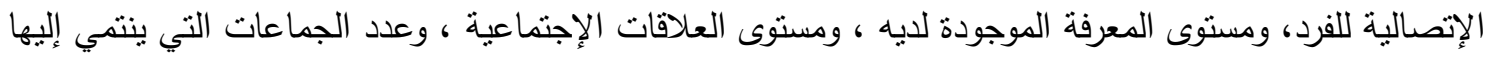
الفرد ، والإتصال الثخصي ، وطبيعة النظام الإعلامي ، والعمليات الإنتقائية في التعرض والإدرالك والتذكر (حلمي ، الإي

. (1990 ،

هذا ويعتبر الإتصال في المجتمع البشري هو بمثابة الجهاز العصبي في الكائن الحي فهو الذي بربط بين

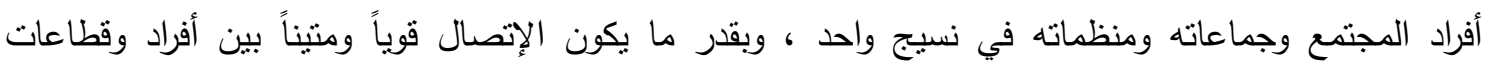

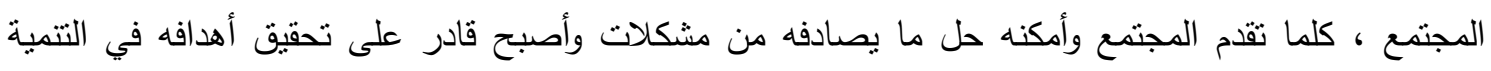

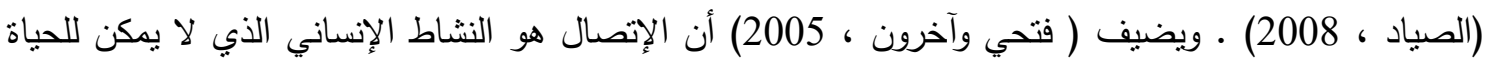
أن تستمر بدونه ، فيعتبر الإتصال بمثابة المركز أو المحور للسلوك الإنساني فالفرد لا يستطيع أن يتفاعل

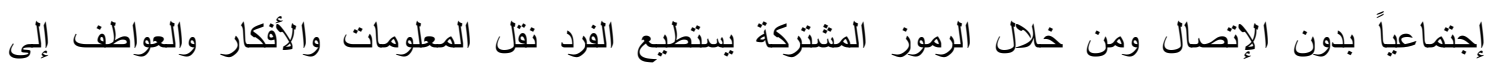
الآخرين.

كما أن الإتصال الذي ينم داخل الفرد يكون إما بالتفكير في شئ ما أو معرفة سبب أو تقييم الفرد لنفسه ،

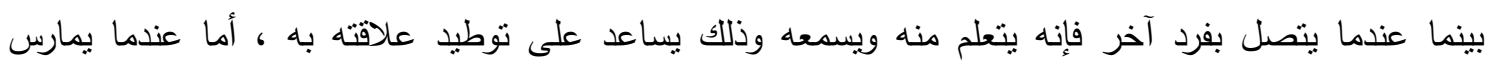

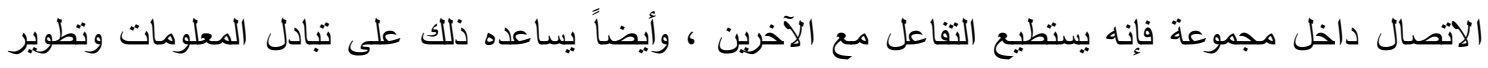

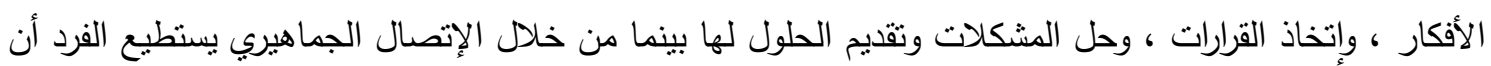

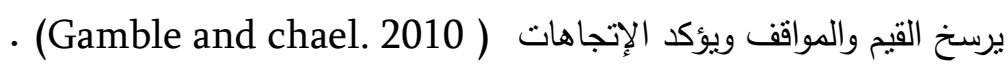
إن الغرض الأساسي من الإتصال هو توجه المتصل نحو المعلومات بإعطائها إهتمامه والتفاعل معها

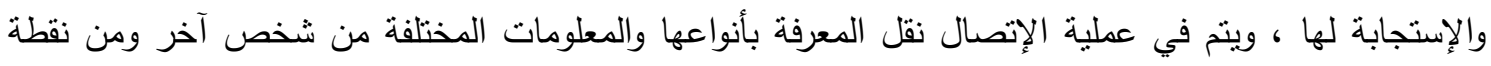
لأخرى وتتخذ لها مساراً يبدأ من المصدر الذي تتبع منه إلى الجهة التي تستقبلها ثم يرتد ثانية إلى المصدر وهكنا (نصر الله ، 2010) • ويعرف الإتصال على أنه عملية نقل المعلومات والإتجاهات وهو عملية مشاركة بين المستقبل والمرسل والمشاركة في الإزدواج في الوجود وهو الإقتراب إلى واقع العملية الإتصالية ، وأيضاً هو عملية ولية الإنية

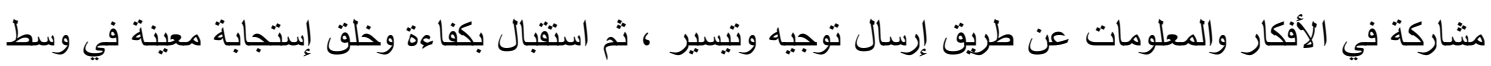

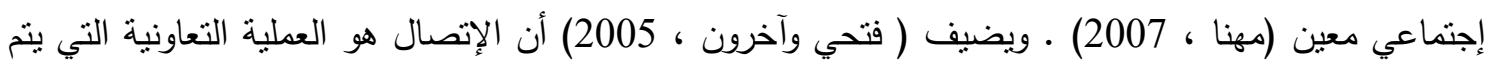

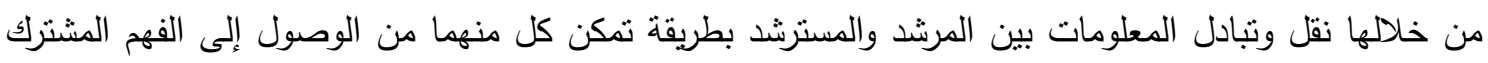

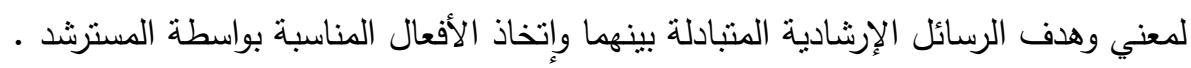


يذكر ( إبراهيم ، 2004 ) أن للإتصال أهداف كثثرة ، ويمكن تقسيمها إلى أهداف عامة ، وأهداف خاصة

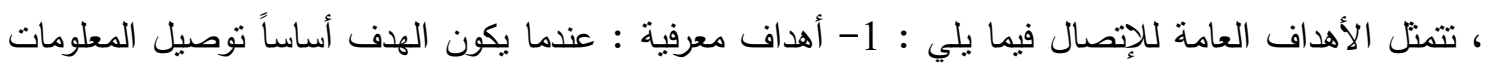
والخبرات 2- أهداف إقناعية: عندما يكون الهدف أساساً تغيير وجهة نظر أو الإقتتاع بشئ 3- أهداف نرويحية :

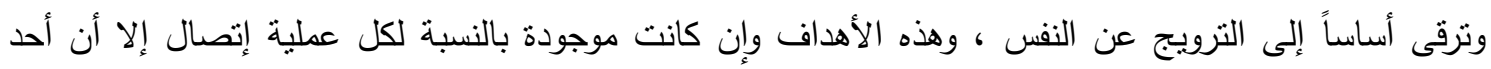

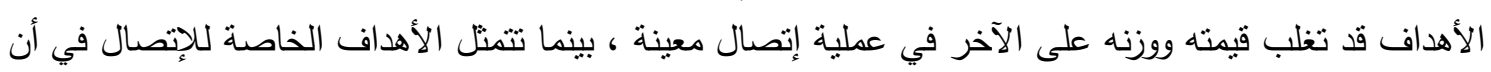

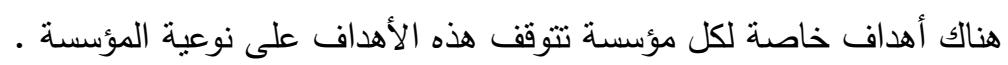
ويفترض(Crokhite. 1976 ) وجود ثلاثة وظائف رئيسية للإتصال ليصبح أكثر تحديداً ومساهمة

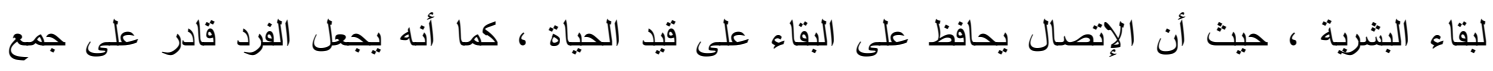

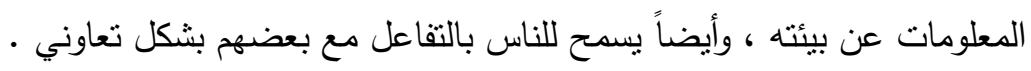
تكنولوجيا المعلومات والإتصالات :

لتكنولوجيا المعلومات والإتصالات دور هام في تعزيز التتمية البشرية والإقتصادية والإجتماعية والثقافية ، وذللك لما لهذه الأجهزة من خصائص متميزة أكثر كفاءة من الوسائل التقليدية فتكنولوجيا المعلومات والإتصال واسعة الإنتشار ، تتخطى بذلك الحدود الجغرافية والسياسية للاول لتصل إلى أي نقطة في العالم عجزت أن أن تصل التصن

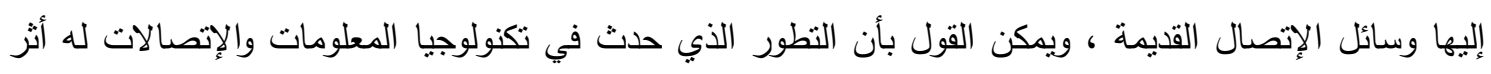

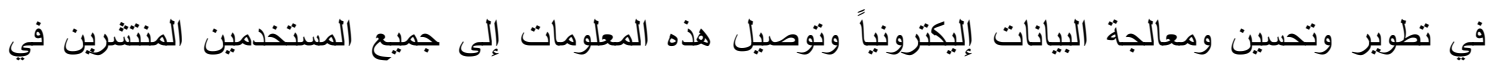

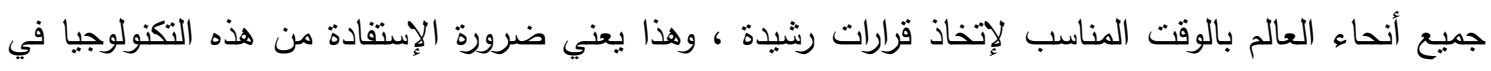
جميع المجالات (عاصم ، 2013) • وقد أدى التقدم الهائل في تكنولوجيا المعلومات والإتصالات ولثاء إلى تغييرات

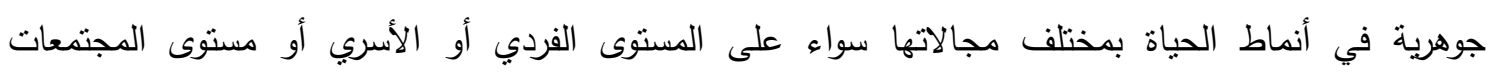

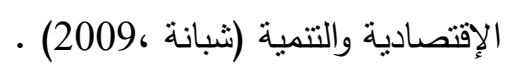

ويرى (Blake. and Harold sen R.H. 1975) أن تكنولوجيا المعلومات والإتصالات هي مجموعة من التقنيات أو الأدوات أو الوسائل أو النظم المختلفة التي ينم توظيفها لمعالجة المضمون أو المحتوى الذي يراد الدياد توصيله من خلال الحاسبات الإلكترونية ، ثم تخزينها ثم إسترجاعها في الوقت المناسب ، ثم نشر هذه الرسائل وفقاً

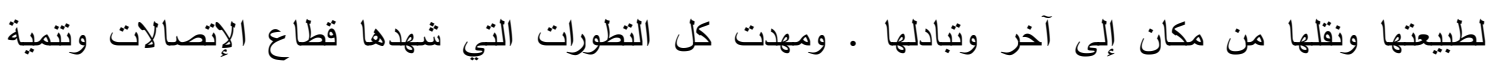

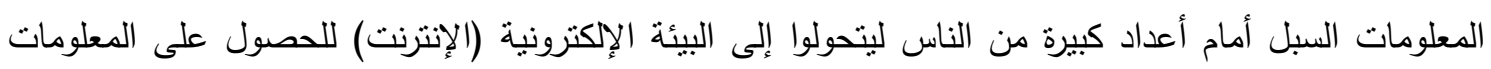

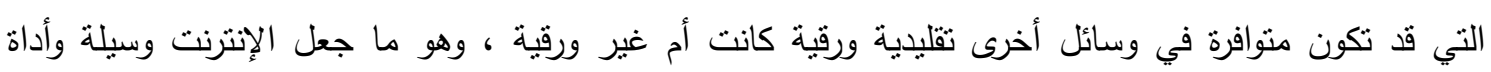
ضرورية في الإتصالات بكافة أثكالها في القرن الحادي والعشرين وتتتافس مع وسائل الإعلام التقليدية في أهدافها

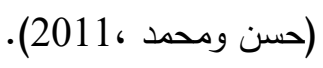
إن تحسين وضع المرأة الريفية وزيادة فعاليتها في تحقيق الأدوار المتوقعة منها في تتمية المجتمع لم تعد

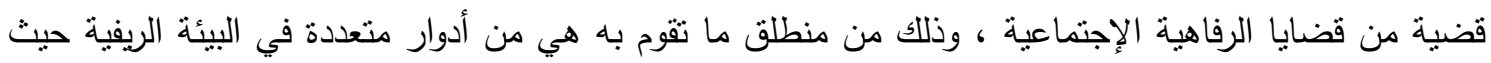

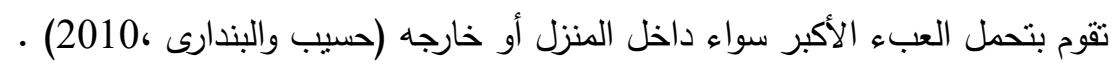
نظريات الإتصال :

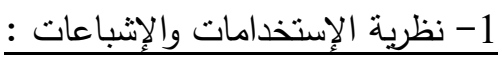

تسمى نظرية المنفعة ، حيث أننا نتعرض وندرك الرسائل السارة لنا والتي تساعدنا على إثباع إحتباجاتتا و نتوقع منها أن تشبع هذه الإحتياجات ، وتنساؤلها عن كيفية إستفادة الجمهور من وسائل الإتصال الجماهيري ، 
وهناك العديد من الإثباعات مثل : البعد عن النفس وعن الآخرين ،التعلم عن كيفية التصرف في مختلف المواقف

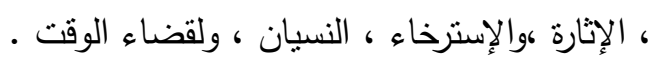

وبهذه النظرية يعتبر الجمهور نشطاً ويمكنه تحديد الإثباعات التي يريد الحصول عليها ويستخدم خبرته

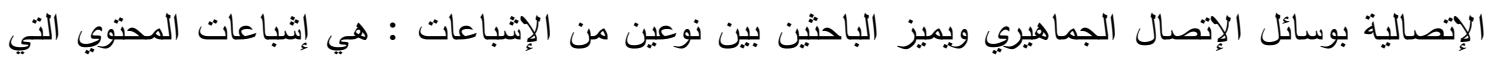

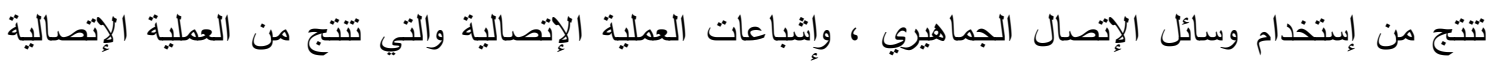

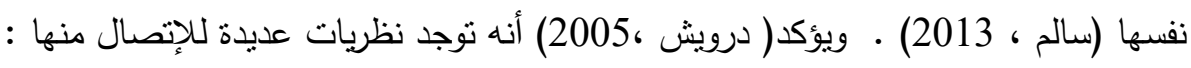

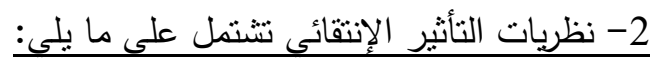

أ- نظرية التأثير الإنتقائي القائم على الإختلافات الفردية : وتعتبر هذه النظرية أن رسائل وسائل الإتصال

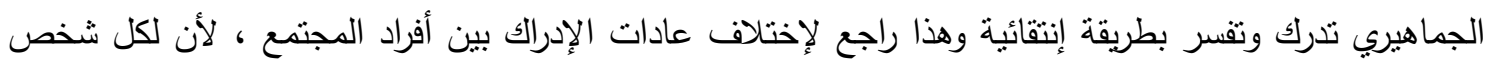

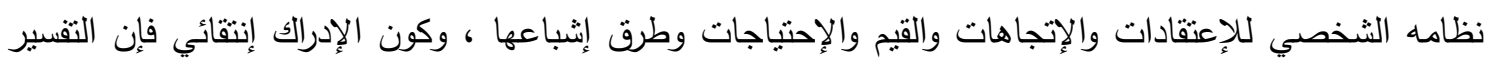

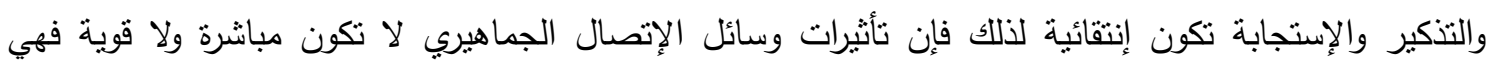
إنتقائية وتحدها الإختلافات النفسية . ويضيف (مكاوي ،2009) أن جمهور وسائل الإعلام ليس جماعة متتاسقة تصنى إلى الرسائل الإتصالية

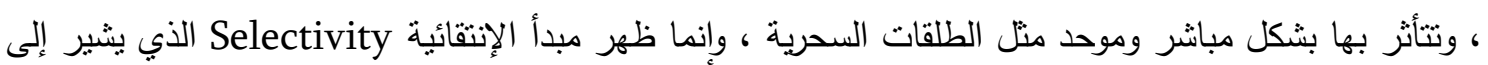

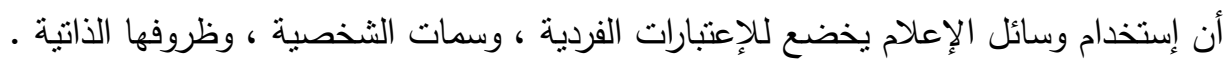
ب- نظرية الإنتقائية القائمة على أساس الفئات الإجتماعية : تعتبر هذه النظرية أن وسائل الإتصال الجماهيري

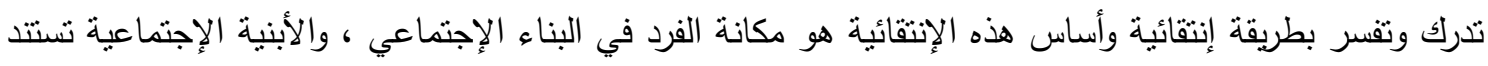

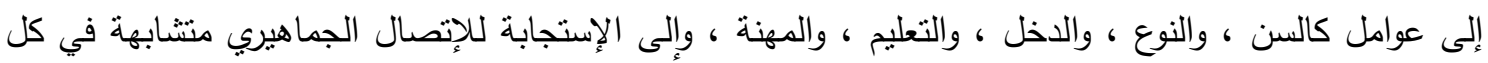
منه وذلك لأن أنماط الإنتباه والإستجابة تنتشابه. ج- نظرية الإنتقائية على أساس العلاقات الإجتماعية : تعتبر أن رسائل وسائل الإتصال الجماهيري تدرك وتفابه الإنسر

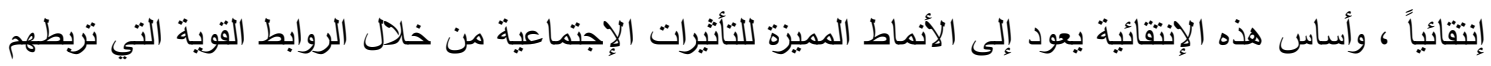

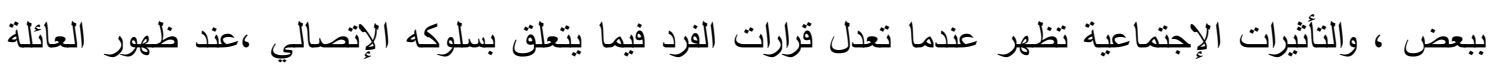
والأصدقاء ، والزملاء أو الآخرين ، وأن أنماط الإستجابة للإتصال الجماهيري تعكس الروابط الإجنماعية لكل أفراد

1- الحالة التعليمية : يقصد بها فى هذا البحث المستوى التعليمى للريفية المبحوثة ، من حيث كونها أمية أو لديها القدرة على القراءة والكتابة أو أتتت مرحلة تعليمية معينة ، معبراً عن ذلك بقيمة رقمية ،وذلك بإعطاء

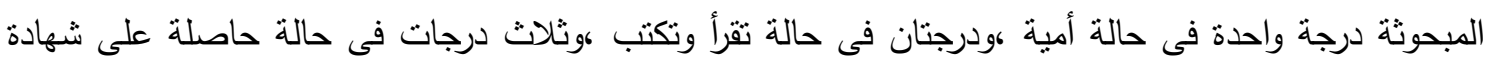

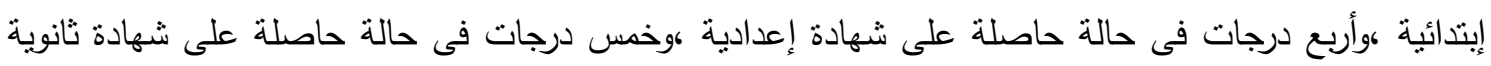

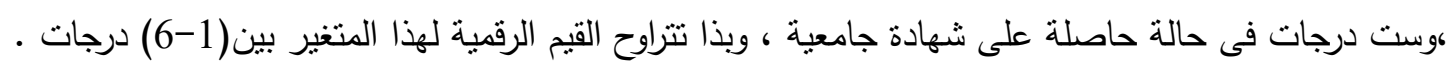
2- الحالة الإجتماعية : يقصد بها فى هذا البحث الوضع الإجتماعى للريفية المبحوثة من حيث كونها متزوجة أوغير متزوجة أو مطلقة أو أرملة ، معبراً عن ذلك بقيمة رقمية ،وذلك بإعطاء المبحوثة أربعة درجات فى حالة الإني 
متزوجة ،وثلاث درجات فى حالة غير متزوجة ،ودرجتان فى حالة أرمله ، ودرجة واحدة فى حالة مطلقة ، وبذا

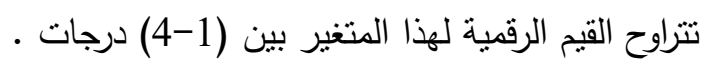
3- الإنفتاح الإنتقالى: يقصد به فى هذا البحث مدى تردد الريفية المبحوثة على الأماكن التى بخارج قريتها سواء كانت قرى مجاورة أو المركز التابع له القرية أو عاصمة المحافظة التى تتنمى إليها أو المحافظات الأخرى ، معبراً عن ذلك بقيمة رقمية ،وذللك بإعطاء المبحوثة درجة واحدة لكل مكان تتردد عليه،وبذا تتراوح القيمة الرقمية لهذا

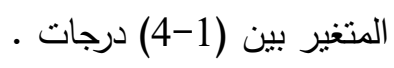
4- مصادر المعلومات : يقصد بها فى هذا البحث عدد المصادر المرجعية التى تلجأ إليها الريفية المبحوثة

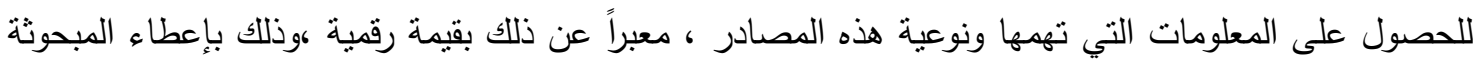

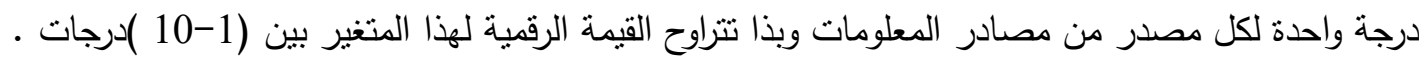
5 -إمتلاك الأسرة لجهاز الحاسب الآلي ومستوى الإستفادة منه : يقصد به فى هذا البحث مدى إمتلاك الأسرة

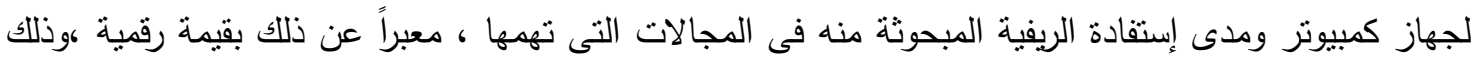

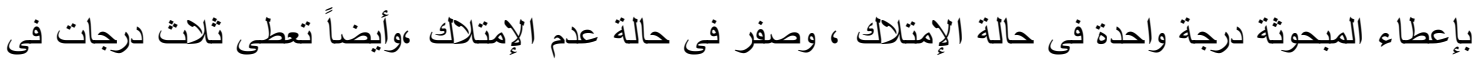

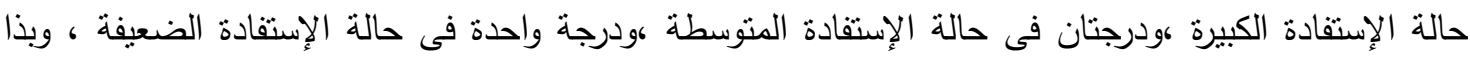
تتزاوح القيمة المعبرة عن هذا المتغير بين (1-4) درجات .

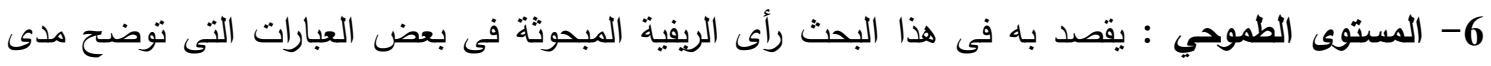

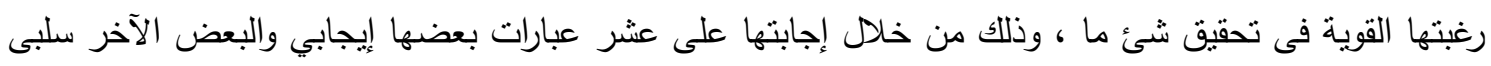

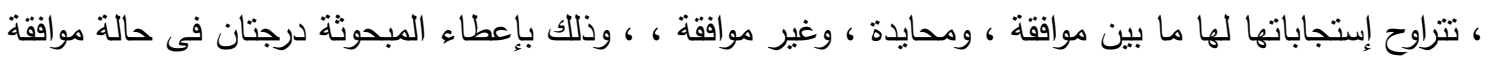

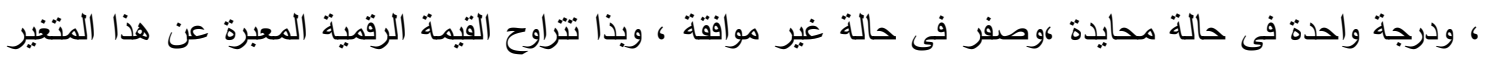

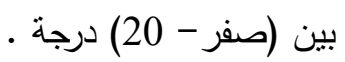

7- التجدية : يقصد بها فى هذا البحث إتجاه الريفية المبحوثة نحو التغيير وذلك من خلال إستجاباتها لعشر عبارات تتراوح درجة الإستجابة لها ما بين موافقة ، و محايدة ،وغير موافقة ، وذلك بإعطاء المبحوثة درجنان فى حالة موافقة ،ودرجة واحدة فى حالة محايدة ،وصفر فى حالة غير موافقة ، وبذا نتراوح القيمة الرقمية المعبرة عن هذا المتغير بين (صفر -20) درجة. 8- الحيازة الأرضية المزرعية : يقصد بها فى هذا البحث مساحة ما تحوزه أسرة الريفية المبحوثة من أرض زراعية مقدرة بالقيراط . 9- القيادية: يقصد به فى هذا البحث الحكم الذى تصدره الريفية المبحوثة على نفسها من حيث إسنتارة الريفيات فى القرية لها فى بعض الأمور التى تهمهم ، معبراً عن ذللك بقيمة رقمية ،حيث تمثلت هذة الأمور فى سبعة أمور

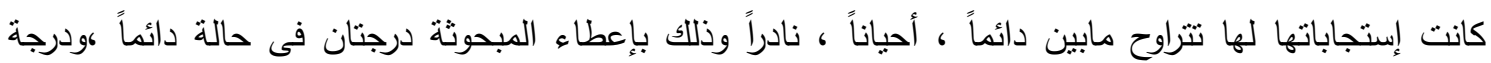

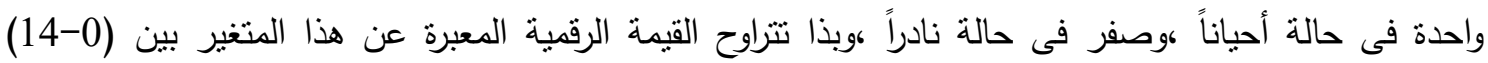

10- مستوى الإستفادة المعرفية : ويقصد بها الدرجة المعبرة عن إستفادة الريفيات المبحوثات من منضمنات أنظمة شبكة إتصال التتمية الريفية والزراعية (رادكون) والمتمثلة في المجالين التاليين : - المجال الإجتماعي ويشتمل على الغذاء والتغذية ،و صحة المرأة ، وصحة الطفل ، وصحة الغذاء ، والتغذية العلاجية والبيئة .

- المجال الإقتصادي ويشتمل على المشروعات الصغيرة . 
ويعبر مستوى الإستفادة المعرفية عن مجموع القيم الرقيمة المعبرة عن إستفادة الريفيات المبحوثات من المجالات

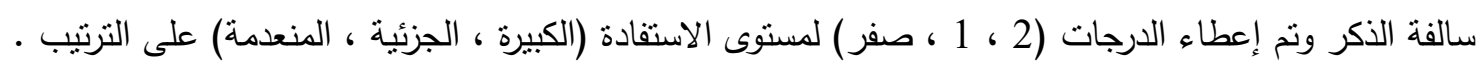
11- مستوى التعرض للشبكة : ويقصد به في هذا البحث عدد مرات تعرض الريفيات المبحوثات لشبكة إتصال

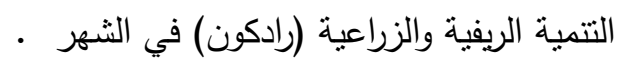
12- المعرفة بأنظمة الثبكة : يقصد بها في هذا البحث مدى معرفة الريفية المبحوثة بأنظمة شبكة إتصال التتمية

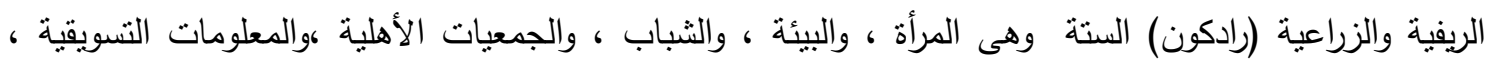

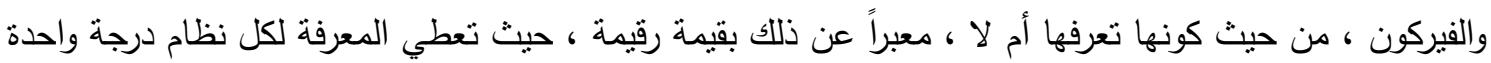

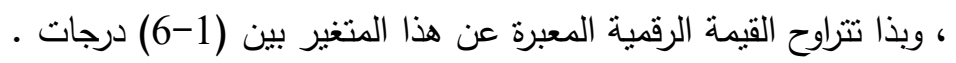

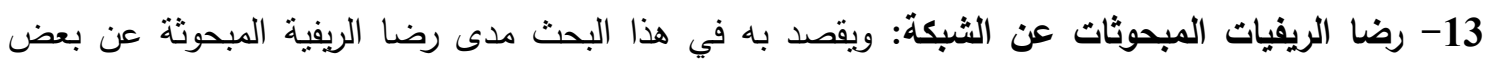

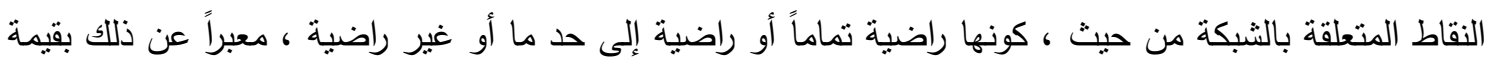

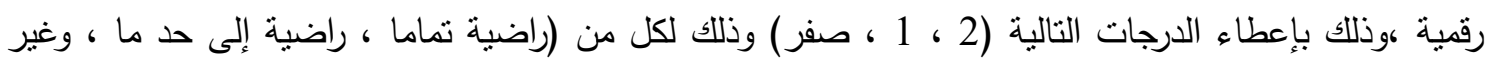

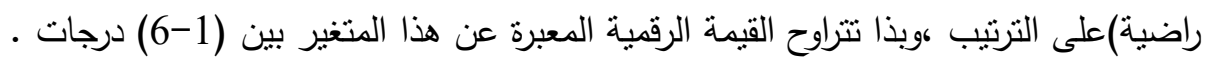
14-المستوى التقييمي لخصائص محتوى الثبكة : يقصد به فى هذا البحث آراء الريفيات المبحوثات فى شبكة

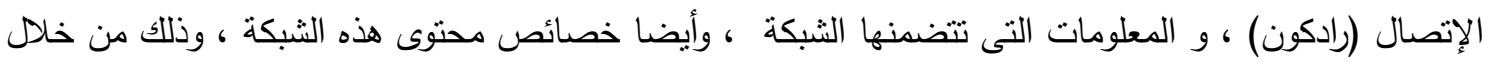
إستجابة المبحوثات إلى 13 عبارة ، بحيث تعطى المبحوثة درجتان فى حالة درجة التقييم الكبيرة ، ودرجة واحدة في

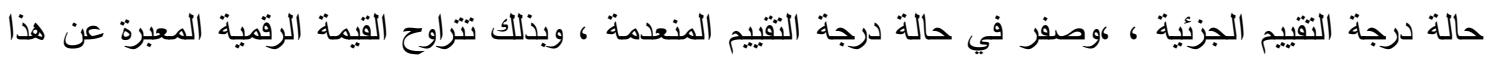
المتغير بين (صفر -26) درجه .

\section{المتغيرات البحثية :}

تمثلت متغيرات هذه الدراسة في متغير تابع وهو مستوى الإستفادة المعرفية للريفيات المبحوثات من

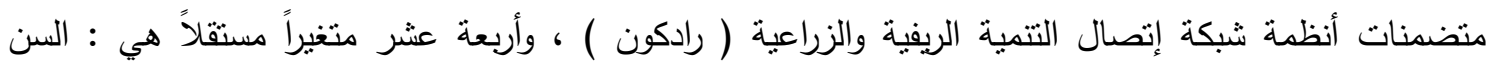
،الحالة التعليمبة ، الحالة الإجتماعية ، الإنفتاح الإنتقالي ، تعدد مصادر المعلومات ، إمتاعلاك الأسرة لجهاز

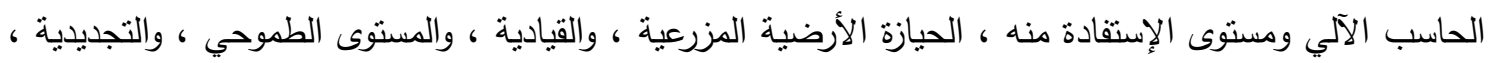

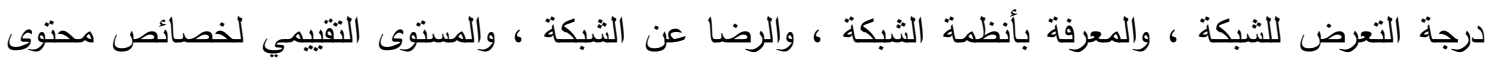
الثبكة

الثاملة والعينة ومنطقة البحث: نم حصر جميع الريفيات المتعرضات و المترددات على شبكة إتصال التتمية

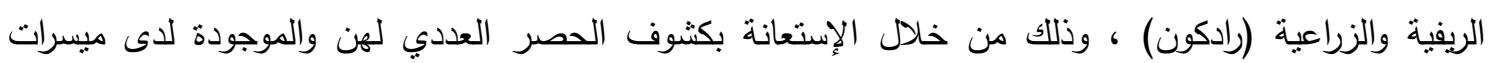

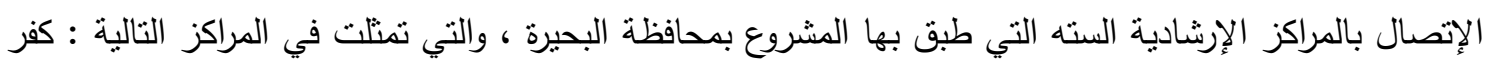

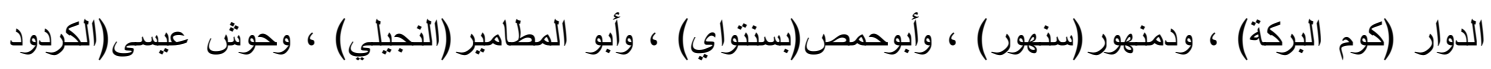

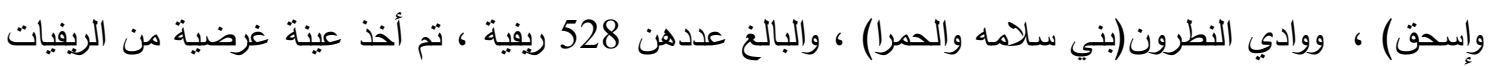
اللآتي تعرضن مرتين فأكثر شهرياً للشبكة حيث بلغ حجم العينة 160 ريفية مبحوثة. ولنة.

\section{الفروض البحثية :}

1-توجد علاقة إرتباطية معنوية بين مسنوى الإستفادة المعرفية للريفيات المبحوثات من منضمنات أنظمة شبكة

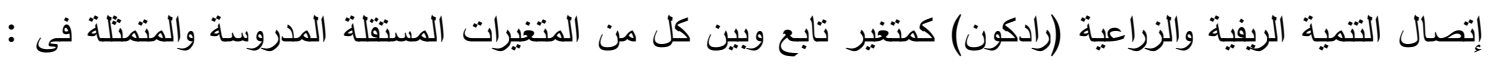

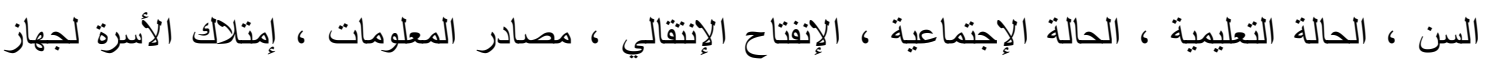


الحاسب الآلي ومستوى الإستفادة منه ، المسنوى الطموحي ، التجددية ، الحيازة الأرضية المزرعية ،القيادية ،

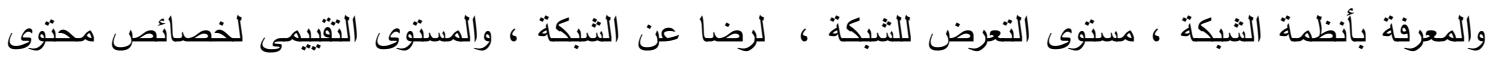
الثبكة .

ويتم إختبار هذا الفرض فى صورته الصفرية (فرض العدم) التالية :

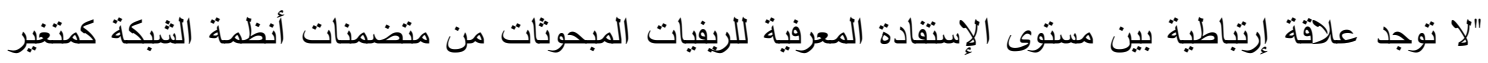

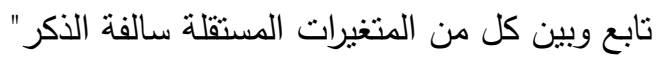
2-يتأثر مستوى الإستفادة المعرفية للريفيات المبحوثات من متضنينات أنظمة شبكة إتصال التتمية الريفية والزراعية

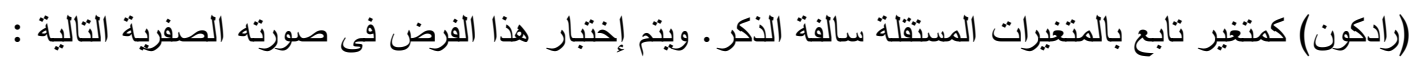
"لايتأثز مستوى الإستفادة المعرفية المعرفية للريفيات المبحوثات من منضمنات أنظمة شبكة إنيكة إتصال التتمية الريفية والزراعية (رادكون) كمتغير تابع بالمتغيرات المستقلة سالفة الذكر". تجميع وتحليل البيانات البحثية :

إعتمد البحث على الإستبيان بالمقابلة الثخصية كوسيلة لتجميع البيانات البحثية ، وإثتمل الإستنيان على ثلاثة محاور رئيسية ، تضمن الأول : بيانات عن الخصائص المميزة للريفيات المبحوثات ، وإنطوى الثاني على البيانات المتعلقة بمستوى الإستفادة المعرفية للريفيات المبحوثات من منضمنات أنظمة شبكة إتصال التتمية الريفية والزراعية (رادكون) ، بينما إثتمل الثالث المشكلات التي تواجه الريفيات عند الإتصال بالثبكة والحلول

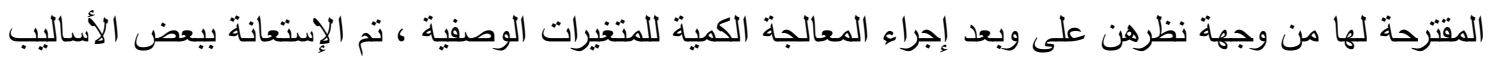
بالطرق الإحصائية لتحليل البيانات البحثية وتحقيق أهداف الدراسة وتمنلت في : النسب المئوية ، والمتوسط الحسابي والإنحراف المعياري والإرتباط البسيط ، و الإنحدار المتعدد ، وقد إستخدم البرنامج الإحصائي (SPSS) وإختبار T ، ونسبة F مي تحليل بيانات الدراسة .

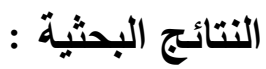

أولا : الخصائص المميزة للريفيات المبحوثات :

1- السن: أوضحت نتائج الدراسة أن سن المبحوثات قد تراوح بين (18 - 70) عاماً ، وبلغ متوسط السن بينهن

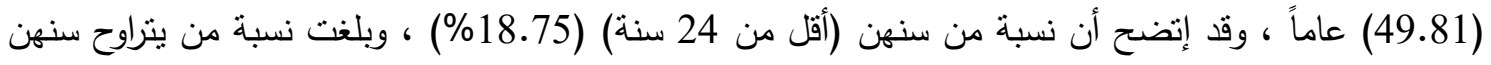
بين(24- 47)سنة (65 \%) ، وأن نسبة من بلغ سنهن(47 سنة فأكثر) (16.25\%) من المجموع الكلي للريفيات

2-الحالة التعليمية :أظهرت النتائج البحثية أن القيم الرقيمة المعبرة عن الحالة التعليمية للريفيات المبحوثة تراوحت بين (1 - 6) درجات وذلك بمنوسط حسابي قدره (3.462 درجة) ، وقد إتضح أن نسبة ذوات المستوى التعليمي

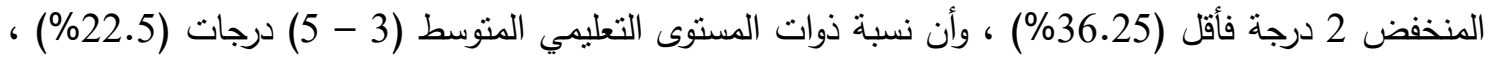

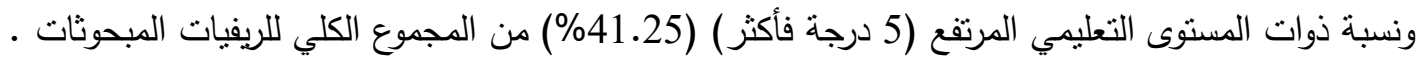

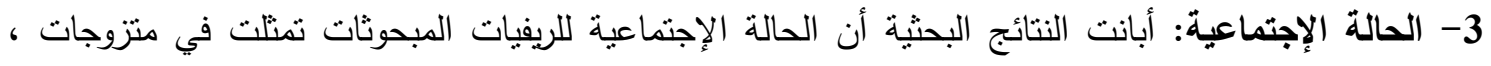

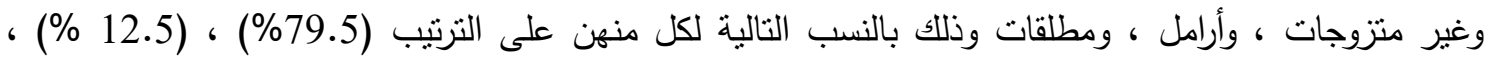

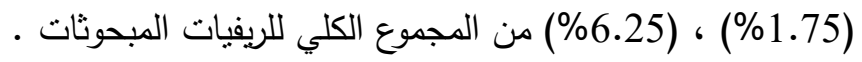
4- الإنفتاح الإنتقالي: أوضحت النتائج البحثية أن القيم الرقمية المعبرة عن الإنفتاح الإنتقالي للريفيات المبحوثات تراوحت بين (1- 4) درجات وذللك بمنوسط حساب قدره (2.962) درجة ، حيث بلغت نسبة الريفيات ذوات الإني 
المستوى الإنتقالي المنخفض(2درجة فأقل) (35\%) ، وأن نسبة ذوات المستوى الإنتقالي المتوسط ( 3 - 4 ( 4 ) درجات (23.25\% ) ونسبة ذوات المسنوى الإنتقالي المرتفع (4 درجة فأكثر) (412.75\%) من وان نسبه دوات المجموع الكلي للريفيات المبحوثات

5- تعدد مصادر المعلومات: أظهرت النتائج البحثية أن عدد المصادر التي تستقي منها الريفيات المبحوثات معلوماتهن نراوحت بين (1 - 10) مصادر ، وذلك بمتوسط حسابي قدره (5.012 درجة) ، حيث بلغت نسبة من

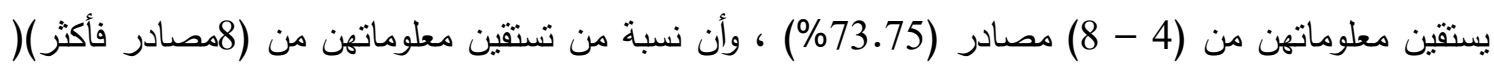

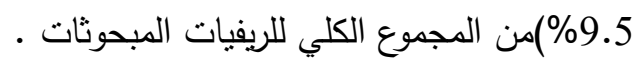
6-إمتلاك الأسرة لجهاز الحاسب الآلي ومستوى الإستفادة منه : أوضحت النتائج البحثية أن(42.5\%)من لرنبات

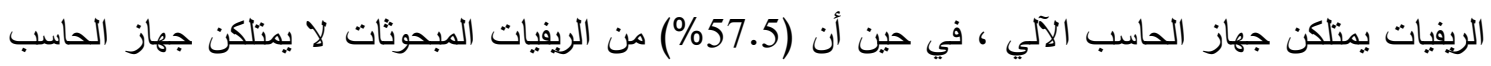

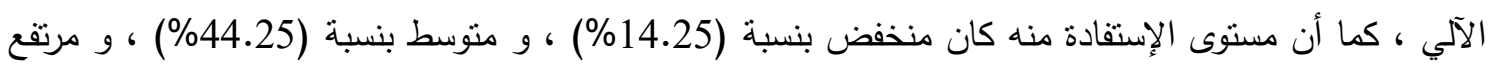
بنسبة (41\%) من المجموع الكلي للريفيات المبحوثات . 7- المستوى الطموحي: أوضحت النتائج البحثية أن القيم الرقمية المعبرة عن هذا المتغير نراوحت بين

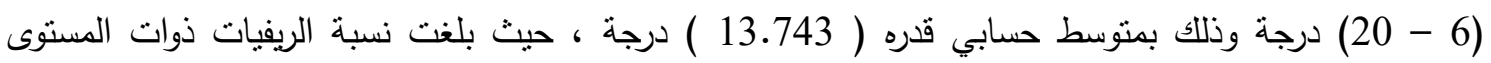
الطموحي المنخفض (11 درجة فأقل) (8.75\%) ، ونسبة ذوات المستوى الطموحي المتوسط (12 (12 16 (12 درجة) (1.75\%) وأن نسبة ذوات المستوى الطموحي المرتفع (16 درجة فأكثر) (19.5\%) من المجموع الكلي للريفيات المبحوثات . 8- التجدية: أوضحت النتائج البحثية أن القيم الرقمية المعبرة عن هذا المتغير تراوحت بين (4 - 18) درجة

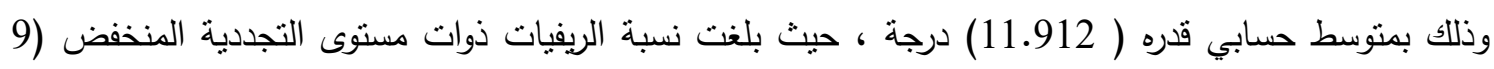

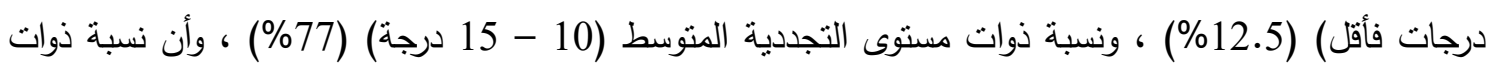
مسنوى التجدية المرتفع (15 درجة فأكثر) (10.5\%) من المجموع الكلي للريفيات المبحوثات . 9- الحيازة الأرضية المزرعية: أوضحت النتائج البحثية أن الحيازات الأرضية المزرعية للريفيات المبحوثات تراوحت بين (صفر - 120) قيراط ، وذللك بمتوسط حسابي قدره (27.16) قيراط ، حيث بلغت نسبة الريفيات ذوات

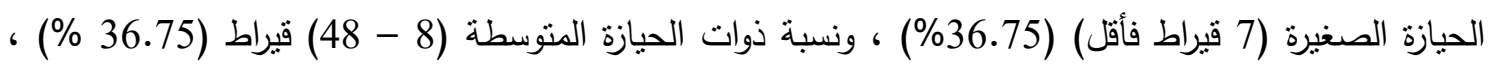
وأن نسبة ذوات الحيازة الكبيرة (48 قيراط فأكثر) (24.5\%) من المجموع الكلي للريفيات المبحوثات . 10- القيادية: أوضحت النتائج البحثية أن القيم الرقمية المعبرة عن هذات المنية المنغير تنراوحت بين

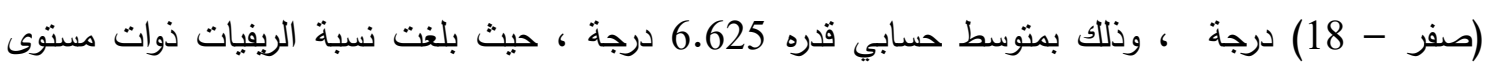

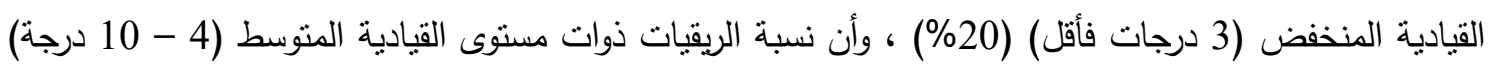

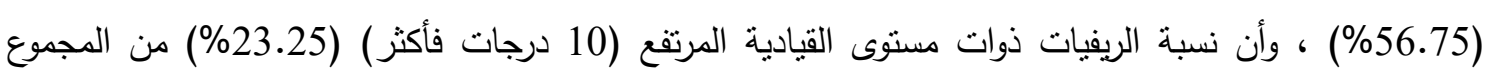
الكلي للريفيات المبحوثات . 11- مستوى التعرض لثبكة الإتصال (رادكون) : أوضحت النتائج البحثية أنه نراوح عدد مرات نعرض الريفيات

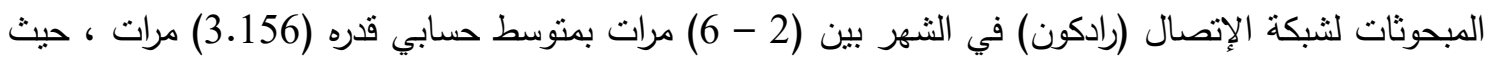

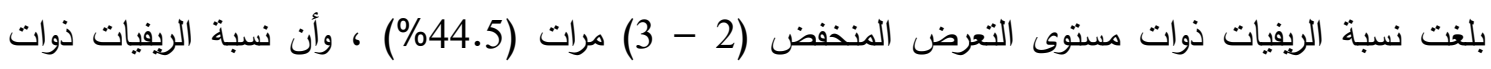
مستوى التعرض المتوسط (3 - 5) مرات (42.5\%) ، في حين بلغت نسبة الريفيات ذوات مستوى التعرض المرتفع (دات

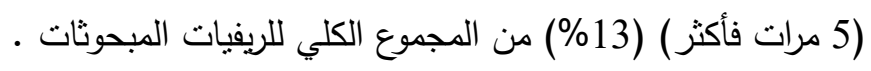


12- المعرفة بأنظمة شبكة الإتصال (رادكون) : أوضحت النتائج البحثية أن القيم الرقية المعبرة عن هذا المتغير

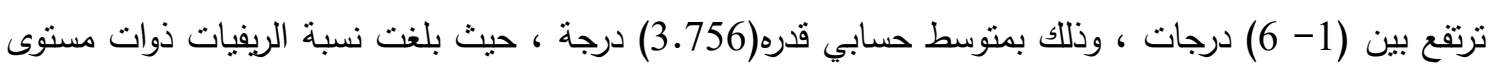

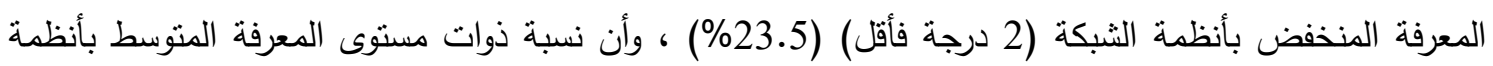
الثبكة (41.75 \%) ، في حين بلغت نسبة الريفيات ذوات مستوى المعرفة المرتفع بأنظمة الثبكة (5 درجات

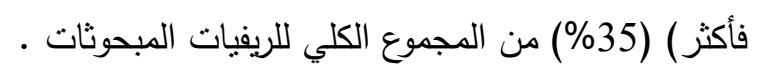

13- الرضا عن شبكة الإتصال (رادكون) : أوضحت النتائج البحثية أن القيم الرقمية المعبرة عن هذا المتغير تراوحت بين (صفر - 24 درجة) ، وذلك بمتوسط حسابي قدره(16.012)درجة ، حيث بلغت نسبة الريفيات ذوات

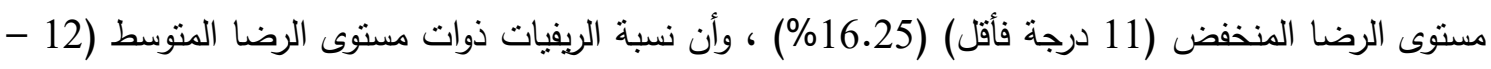
21 درجة) (25.25\%) ، في حين بلغت نسبة الريفيات ذوات مستوى الرضا المرتفع (21 درجة فأكثر) (22.5\%)

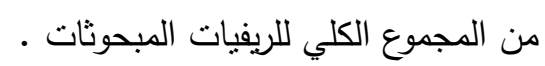
14- المستوى التقييمي لخصائص محتوى الثبكة : أوضحت النتائج البحثية أن القيم الرقية المعبرة عن هذا المتغير تراوحت بين (صفر -26درجة) وذلك بمنوسط حسابي قدره (18.174\%) درجة ، حيث بلغت نسبة

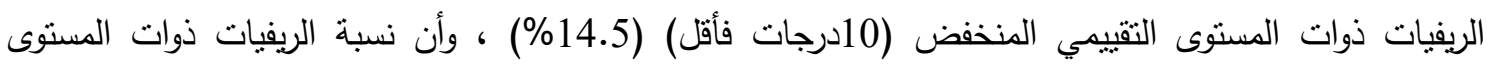
التقييمي المتوسط (11-19درجة) (71.75\%) ، في حين بلغت نسبة الريفيات ذوات المسنوى التقييمي المرتفع (19درجة فأكثر) (13.75\%) من المجموع الكلي للريفيات المبحوثات . 
جدول رقم (1) توزيع الريفيات المبحوثات وفقا للخصائص المميزة لهن

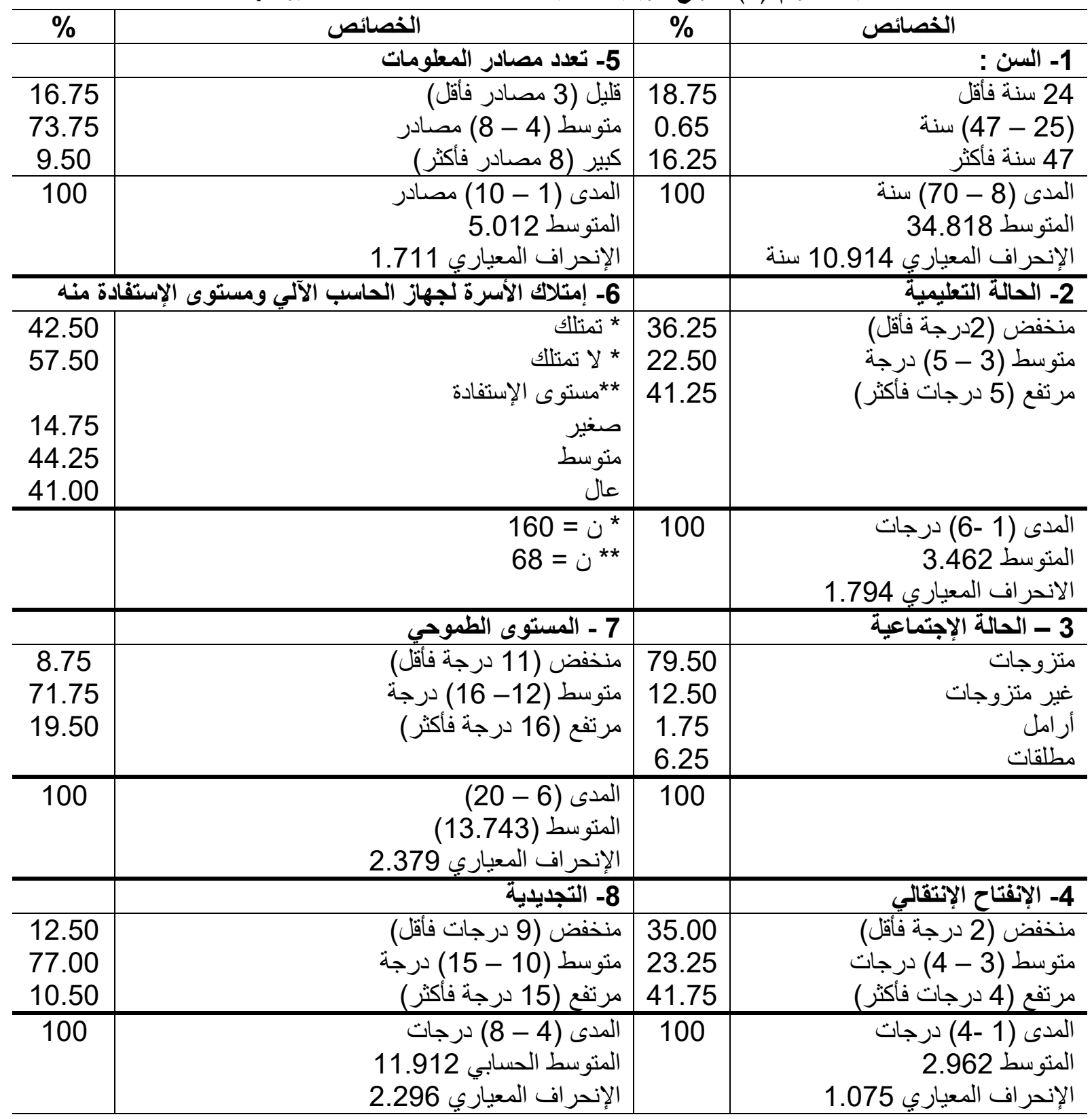


تابع جدول رقم (1) توزيع الريفيات المبحوثات وفقاً للخصائص المميزة لهن

\begin{tabular}{|c|c|c|c|}
\hline$\%$ & الخصائص & $\%$ & الخصائص \\
\hline & 12- المعرفة بأنظمة الشبكة & & 9- الحيازة الأرضية المزرعية \\
\hline 23.50 & منخفض (2 درجة فأقل) & 36.75 & صغيرة (7 قير اط) فأقل \\
\hline 41.75 & متوسط (3 - 5) درجة & 38.75 & متوسطة (8 - 48) قير اط \\
\hline 35.00 & مرتفع (5 درجات فأكثر) & 24.50 & كبيرة (48 قير اط) فأكثر \\
\hline \multirow[t]{4}{*}{100} & المدى (1 - 6) درجات & 100 & المدى (صفر - 120) قير اط \\
\hline & المتوسط 13.756 & & المنوسط 27.162 \\
\hline & الإنحر اف المعياري 1.666 & & الإنحر اف المعياري 20.133 \\
\hline & 13- الرضا عن الشبكة & & 10 \\
\hline 16.25 & منخفض (11 درجة فأقل) & 20.00 & منخفض (3 درجات فأقّل) \\
\hline 61.25 & منوسط (12- 21) درجة & 56.75 & منوسط (4 - 10) درجات \\
\hline 22.50 & مرتفع (21 درجة فأكثر) & 23.25 & مرتفع (10 درجات) فأكثر \\
\hline \multirow[t]{4}{*}{100} & المدى (صفر - 24) & 100 & المدى (صفر - 18) درجة \\
\hline & المتوسط 16.012 & & المتوسط 6.625 \\
\hline & الإنحر اف المعياري 5.386 & & الإنحر اف المعياري3.311 \\
\hline & 14- المستوى التقييمي لخصائص محتوى الثبكة & & 11 - مستوى التعرض للشبكة \\
\hline 14.50 & منخفض (10درجة فأقلَ) & 44.50 & منخفض (2 درجة فأقلَ) \\
\hline 71.75 & متوسط (11-19) درجة & 42.50 & متوسط (3 - 5) درجات \\
\hline 13.75 & مرتفع (19درجة فأكثر) & 13.00 & مرتفع (5 درجات) فأكثر \\
\hline \multirow[t]{3}{*}{100} & المدى (صفر -26) درجة & 100 & المدى (2 - 6) درجة \\
\hline & المتوسطُ174.174 & & المتوسط 3.156 \\
\hline & الإنحر اف المعياري 7.447 & & الإنحر اف المعياري 1.523 \\
\hline
\end{tabular}

ثانيا : مستوى الإستفادة المعرفية للريفيات المبحوثات من متضمنات أنظمة شبكة إتصال التنمية الريفية والزراعية (رادكون) مستوى الإستقادة المعرفية العام : أوضحت النتائج البحثية أن مستوى الإستفادة المعرفية العام من المجالات المتضمنة بأنظمة شبكة إتصال التتمية الريفية والزراعية (رادكون) يتراوح بين (10 - 122) درجة ، وذلك بمتوسط حسابي قدره(81.812)درجة ، وإنحراف معياري قدره(28.673)درجة ، حيث أنه تم تقسيم مستوى الإستفادة المعرفية من المجالات المتضمنة

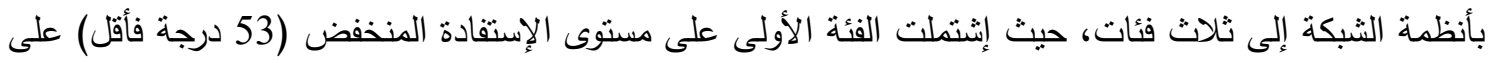
(16.25\%) من إجمالي الريفيات المبحوثات وإشتملت الفئة الثانية على مستوى الإستفادة المتوسط الإنى

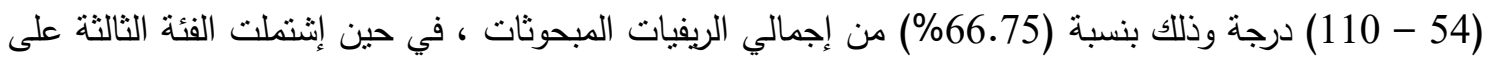
مستوى الإستفادة المرتفع (110 درجة فأكثر) وذللك بنسبة(17\%)من إجمالي الريفيات المبحوثات ، جدول رقم (2) 
جدول رقم (2) توزيع الريفيات المبحوثات وفقاً لفئات مستوى الإستفادة المعرفية لمتضمنات أنظمة شبكة إتصال التنمية الريفية و الزراعية (رادكون)

\begin{tabular}{|c|c|c|}
\hline$\%$ & العدد & مستوى الإستفادة المعرفية (درجة) \\
\hline 16.25 & 26 & منخفض (53 درجة فأقل) \\
\hline 66.75 & 107 & متوسط (54 - 110) درجة \\
\hline 17.00 & 27 & مرتفع(110 درجة فأكثر) \\
\hline 100 & 160 & المجمـوع \\
\hline
\end{tabular}

يتضح من الجدول السابق أن غالبية الريفيات المبحوثات(83.75\%) يقعن في الفئة متوسطة ومرتفعة الإستفادة المعرفية ، مما يدل على أهمية شبكة إتصال التتمية الريفية والزراعية (رادكون) من تزويد الريفيات

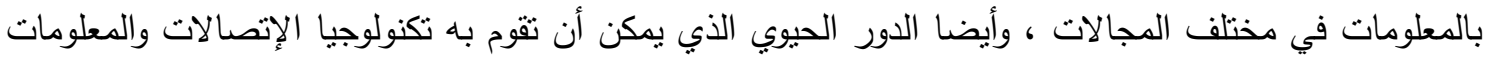

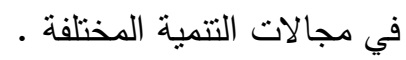
أولاً: الإستفادة المعرفية فيما يتعلق بالمجال الإجتماعي والغذائي والصحي : ويتضمن هذا المجال ستة محاور

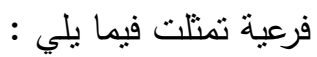
1-الغذاء والتنظية : ويشتمل هذا المحور على سبعة مكونات فرعية تمثلت في : أطباق للمناسبات ، وأطباق يومية ، ووصفات جدني ، ومكونات الوجبات المتكاملة ، وطرق حفظ وتخزين الغذاء ، وإنتاج الغذاء ، ومعلومات غذائية أخرى . أ- أطباق للمناسبات:

جدول رقم (3) توزيع الريفيات المبحوثات وفقاً لإستفادتهن المعرفية من مكون أطباق للمناسبات

\begin{tabular}{|c|c|c|c|c|c|c|c|c|}
\hline \multirow{2}{*}{$\%$} & \multirow{2}{*}{ المجمو } & \multicolumn{2}{|c|}{ منعدمة } & \multicolumn{2}{|c|}{ جزئية } & \multicolumn{2}{|c|}{ كبيرة } & \multirow{2}{*}{ أطباق كلمظلسيات الإستفادة } \\
\hline & & $\%$ & العدد & $\%$ & العدد & $\%$ & العدد & \\
\hline 100 & 160 & 9.50 & 16 & 21.75 & 35 & 68.75 & 110 & الكعلك و البسكويت \\
\hline 100 & 160 & 41.75 & 67 & 20.75 & 33 & 37.50 & 60 & تورتة عيد الميلاد \\
\hline 100 & 160 & 65.00 & 104 & 15.50 & 25 & 19.50 & 31 & العاشور اء \\
\hline 100 & 160 & 38.75 & 62 & 19.50 & 31 & 41.75 & 67 & المتوسط العام للإستفادة \\
\hline
\end{tabular}

يتضح من الجدول السابق ان أكثر من نصف الريفيات المبحوثات ( 61.25 \% ) كن ذوات إستفادة معرفية كبيرة وجزئية من مكون أطباق للمناسبات ، مما يدل على إسهام هذا المكون في تزويد الريفيات بالمعلومات

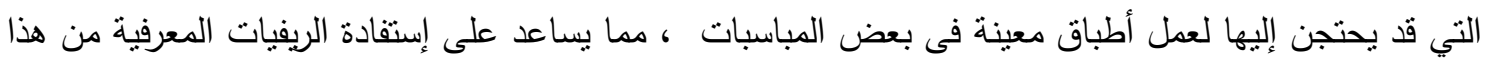

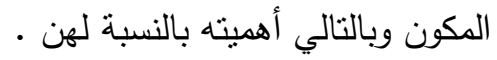
ب- أطباق يومية:

جدول رقم (4) توزيع الريفيات المبحوثات وفقاً لإستفادتهن المعرفية من مكون أطباق يومية

\begin{tabular}{|c|c|c|c|c|c|c|c|c|}
\hline \multirow{2}{*}{$\%$} & \multirow{2}{*}{ المجموع } & \multicolumn{2}{|c|}{ منعدمة } & \multicolumn{2}{|c|}{ جزئية } & \multicolumn{2}{|c|}{ كبيرة } & \multirow[t]{2}{*}{ الإستفادة } \\
\hline & & $\%$ & العدد & $\%$ & 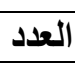 & $\%$ & العدد & \\
\hline 100 & 160 & 16.25 & 26 & 25.50 & 41 & 58.25 & 93 & مكرونة بالبشاميل \\
\hline 100 & 160 & 24.50 & 39 & 32.50 & 2 & 43.00 & 69 & جلاش باللحم المفروم \\
\hline 100 & 160 & 67.50 & 108 & 2.00 & 3 & 30.50 & 49 & أطباق أخرى \\
\hline 100 & 160 & 36.25 & 58 & 20.00 & 32 & 43.75 & 70 & المتوسط العام للإستفادة \\
\hline
\end{tabular}


يتبين من الجدول السابق أن ( 43.75\% )من الريفيات المبحوثات كانت درجة إستفادتهن من مكون أطباق يومية

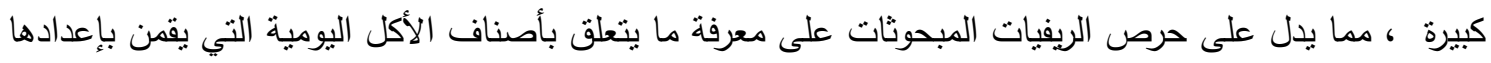

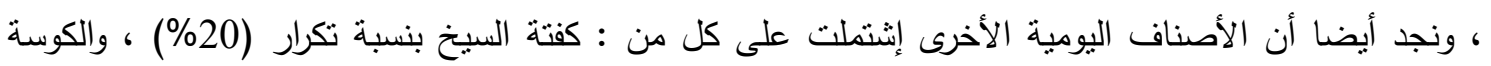

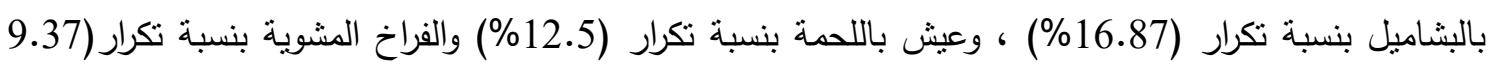

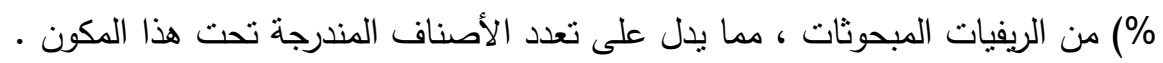

ج- وصفات جدنى:

جلول رقم (5) توزيع الريفيات المبحوثات وفقاً لإستفادتهن المعرفية من مكون وصفات جلتي

\begin{tabular}{|c|c|c|c|c|c|c|c|c|}
\hline \multirow{2}{*}{$\%$} & \multirow{2}{*}{ المجمو } & \multicolumn{2}{|c|}{ منعدمة } & \multicolumn{2}{|c|}{ جزئية } & \multicolumn{2}{|c|}{ كبيرة } & \multirow[t]{2}{*}{ الإستفادة } \\
\hline & & $\%$ & العدد & $\%$ & العدد & $\%$ & 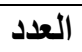 & \\
\hline 100 & 160 & 26.25 & 42 & 20.50 & 33 & 53.25 & 85 & الكثري \\
\hline 100 & 160 & 37.50 & 60 & 18.00 & 29 & 44.50 & 71 & الفول التنابت \\
\hline 100 & 160 & 75.50 & 121 & 3.25 & 5 & 21.25 & 34 & وصفات أخرى \\
\hline 100 & 160 & 46.75 & 75 & 13.75 & 22 & 39.50 & 63 & المتوسط العام للإستفادة \\
\hline
\end{tabular}

جدول رقم (6) توزيع الريفيات المبحوثات وفقاً لإستفادتهن المعرفية من مكون مكونات الوجبات المتكاملة

\begin{tabular}{|c|c|c|c|c|c|c|c|c|}
\hline \multirow[b]{2}{*}{$\%$} & \multirow[b]{2}{*}{ المجموع } & \multicolumn{2}{|c|}{ منعدمة } & \multicolumn{2}{|c|}{ جزئية } & \multicolumn{2}{|c|}{ كبيرة } & \multirow{2}{*}{ مكونات الوجباته للمتكاملة } \\
\hline & & $\%$ & 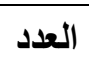 & $\%$ & العدد العد & $\%$ & 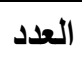 & \\
\hline 100 & 160 & 11.25 & 18 & 28.25 & 45 & 60.50 & 97 & بروتين \\
\hline 100 & 160 & 11.75 & 19 & 32.00 & 51 & 56.25 & 90 & كربو هيدرات \\
\hline 100 & 160 & 14.20 & 23 & 32.00 & 51 & 53.75 & 86 & دهون \\
\hline 100 & 160 & 13.00 & 21 & 33.25 & 53 & 53.75 & 86 & فيتامينات \\
\hline 100 & 160 & 12.50 & 20 & 31.25 & 50 & 56.25 & 90 & المتوسط العام للإستفادة \\
\hline
\end{tabular}

يتضح من الجدول السابق أن أكثر من نصف الريفيات المبحوثات (56.25\%) يتمتعن بمستويات معرفية كبيرة ،

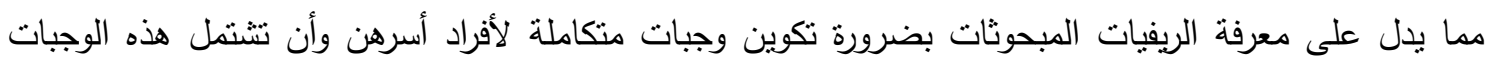

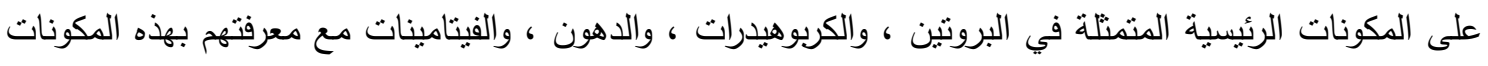

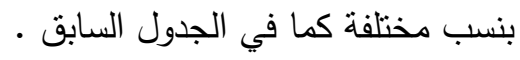
هـ طرق حفظ وتخزين الغذاء:

جدول رقم (7) توزيع الريفيات المبحوثات وفقاً لإستفادتهن المعرفية من مكون طرق حفظ وتخزين الغذاء

\begin{tabular}{|c|c|c|c|c|c|c|c|c|}
\hline \multirow{2}{*}{$\%$} & \multirow{2}{*}{ المجموع } & \multicolumn{2}{|c|}{ منعدمة } & \multicolumn{2}{|c|}{ جزئية } & \multicolumn{2}{|c|}{ كبيزة } & \multirow{2}{*}{ طرق حفظ وتخزين الإنظاء } \\
\hline & & $\%$ & العدد & $\%$ & العدد & $\%$ & العدد العد & \\
\hline 100 & & 2.50 & & 17.50 & 28 & 80.00 & 128 & التجميد \\
\hline 10 & & 0 & 10 & 0.00 & 0 & & 8 & طرق أخرى \\
\hline 100 & 160 & 48.75 & 100 & 8.75 & 14 & 42.50 & 68 & المتوسط العام للإستفادة \\
\hline
\end{tabular}

يظهر من الجدول السابق أن غالبية الريفيات المبحوثات (80\%) كانت معرفتهن كبيرة بطريقة التجميد ، في حين كانت معرفتهن منعدمة بنسبة (95\%) بالنسبة لطرق الحفظ والتخزين الأخرى ، حيث بلغت نسبة معرفتهن للطرق 
الأخرى 5\% ، وتمنتات هذه الطرق في التمليح بنسبة نكرار (21.87\%) ، والمربات بنسبة تكرار (15\%)،

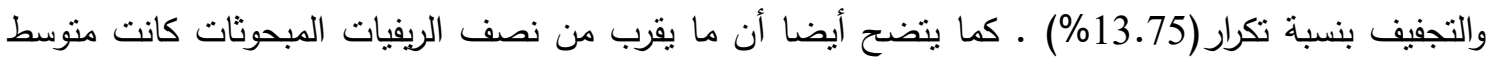
إستفادتهن من هذا المكون منعدمة (48.75 \% مما يدل على ضرورة تفعيل هذا المكون حتى تتمكن الريفيات من تحصيل أقصى إستفادة ممكنة . و - إنتاج الغذاء :

جدول رقم (8) توزيع الريفيات المبحوثات وفقاً لإستفادتهن المعرفية من مكون إنتاج الغذاء

\begin{tabular}{|c|c|c|c|c|c|c|c|c|}
\hline \multirow{2}{*}{$\%$} & \multirow{2}{*}{ المجموع } & \multicolumn{2}{|c|}{ منعدمة } & \multicolumn{2}{|c|}{ جزئية } & \multicolumn{2}{|c|}{ كبيرة } & \multirow{2}{*}{ إنتاج الغذاء الإستفادة } \\
\hline & & $\%$ & العدد & $\%$ & العدد & $\%$ & العدد & \\
\hline 100 & 160 & 10.50 & 17 & 24.50 & 39 & 65.00 & 104 & الحلويات \\
\hline 100 & 160 & 62.50 & 100 & 6.25 & 10 & 31.25 & 50 & أصناف أخرى \\
\hline 100 & 160 & 36.75 & 59 & 15.00 & 24 & 48.25 & 77 & المتوسط العام للإستفادة \\
\hline
\end{tabular}

يتضح من الجدول السابق أن ما يقرب من نصف المبحوثات (48.25 \%) تتمتعن بإستفادة معرفة كبيرة فيما يتعلق بمكونات إنتاج الغذاء ، مما قد يذل على حرص المبحوثات على معرفة منضمنات هذا المكون وإنفادتهن منه ، كما أن الأصناف الأخرى تمنلت في المخبوزات بنسبة تكرار (26.87\%)، والطحينة بنسبة تكرار (15.62\%)

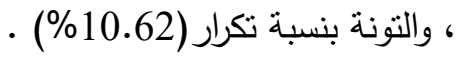
ز - معلومات غذائية :

جدول رقم (9) توزيع الريفيات المبحوثات وفقاً لإستفادتهن المعرفية من مكون معلومات غذائية

\begin{tabular}{|c|c|c|c|c|c|c|c|c|}
\hline \multirow[b]{2}{*}{$\%$} & \multirow[b]{2}{*}{ المجموع } & \multicolumn{2}{|c|}{ منعدمة } & \multicolumn{2}{|c|}{ جزئية } & \multicolumn{2}{|c|}{ كبيرة } & \multirow{2}{*}{ معلومات غذانية: الإستفادة } \\
\hline & & $\%$ & العدد & $\%$ & العدد & $\%$ & العدد & \\
\hline 100 & 160 & 17.00 & 27 & 28.75 & 46 & 54.25 & 87 & السمنة \\
\hline 100 & 160 & 20.75 & 33 & 28.75 & 46 & 50.50 & 81 & النحافة \\
\hline 100 & 160 & 18.75 & 30 & 28.75 & 46 & 52.50 & 84 & المتوسط العام للإستفادة \\
\hline
\end{tabular}

يتضح من الجدول السابق أن أكثر من نصف الريفيات المبحوثات (52.50) يتمتعن بإستفادة كبيرة من مكون المعلومات الغذائية ، مما يدل على أن الريفيات المبحوثات يحرصن على معرفة كل ما يتعلق بالسمنة والنحافة

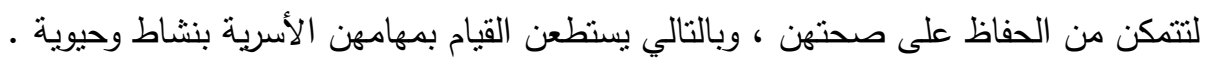
2- 2 - 2 صحة المرأة:

ويتضدن هذا المحور مكونين رئيسيين هما : المعرفة بوسائل تتظيم الأسرة ، ونشرات لصحة المرأة كما يلي :

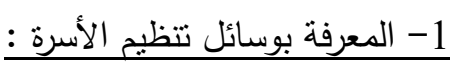
جدول رقم (10) توزيع الريفيات المبحوثات وفقاً لإستفادتهن المعرفية من مكون المعرفة بوسائل تنظيم الأسرة

\begin{tabular}{|c|c|c|c|c|c|c|c|c|}
\hline \multirow{2}{*}{$\%$} & \multirow{2}{*}{ المجموع } & \multicolumn{2}{|c|}{ منعدمة } & \multicolumn{2}{|c|}{ جزئية } & \multicolumn{2}{|c|}{ كبيرة } & \multirow{2}{*}{ وسائل تنظيم الأسترة الإستفادة } \\
\hline & & $\%$ & العدد & $\%$ & العدد & $\%$ & العدد & \\
\hline 100 & 160 & 13.75 & 22 & 31.25 & 50 & 55.00 & 88 & اللولب \\
\hline 100 & 160 & 23.75 & 38 & 28.25 & 46 & 47.50 & 76 & الحقن \\
\hline 100 & 160 & 41.00 & 66 & 24.50 & 39 & 34.00 & 55 & الحبوب \\
\hline 100 & 160 & 26.25 & 42 & 28.25 & 45 & 45.50 & 73 & المتوسط العام للإستفادة \\
\hline
\end{tabular}


يتضح من الجدول السابق أن ما يقرب من نصف الريفيات المبحوثات (45.5 \% كانت إستفادتهن كبيرة من مكون المعرفة بوسائل تتظيم الأسرة ، ، مما قد يدل على أن الريفيات يقبلن على معرفة الوسائل التي تناعدهن

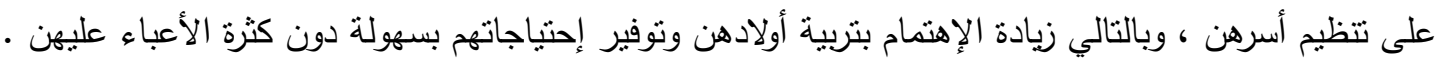
2- 2 نشرات لصحة المرأة:

جدول رقم (11) توزيع الريفيات المبحوثات وفقاً لإستفادتهن المعرفية من مكون نشرات لصحة المرأة

\begin{tabular}{|c|c|c|c|c|c|c|c|c|}
\hline \multirow{2}{*}{$\%$} & \multirow{2}{*}{ المجمو ع } & \multicolumn{2}{|c|}{ منعدمة } & \multicolumn{2}{|c|}{ جزئية } & \multicolumn{2}{|c|}{ كبيرة } & \multirow{2}{*}{ نشرات لصحة المرأه الإستفادة } \\
\hline & & $\%$ & 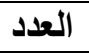 & $\%$ & 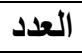 & $\%$ & 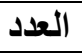 & \\
\hline 100 & 160 & 28.75 & 46 & 25.00 & 40 & 46.25 & 74 & الزواج المبكر المبر \\
\hline 100 & 160 & 13.75 & 22 & 23.75 & 38 & 62.50 & $\begin{array}{l}10 \\
0\end{array}$ & تغذية الحو امل \\
\hline 100 & 160 & 18.25 & 29 & 26.75 & 43 & 55.00 & 88 & التغذية في مرحلة الثباب (المر اهقة) \\
\hline 100 & 160 & 18.00 & 29 & 22.50 & 36 & 59.50 & 95 & تغذية المرضعات \\
\hline 100 & 160 & 20.00 & 32 & 24.50 & 39 & 55.50 & 89 & المتوسط العام للإستفادة \\
\hline
\end{tabular}

يتضح من الجدول السابق أن أكثر من نصف الريفيات المبحوثات(55.5\%) كانت إستفادتهن المعرفية كبيرة من مكون نشرات لصحة المرأة حيث بلغت نسبتهن ، مما يدل على أهية المعلومات المتضمنة بهذا المكون بالنسبة لهن ، حيث أن هذه المعلومات تساعدهن على الإهتمام بصحتهن في المراحل العمرية المختلفة وبالتالي

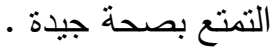

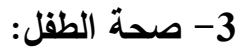

أوضحت النتائج البحثية فيما يتعلق بمحور صحة الطفل أنه يتضمن أربعة مكونات فرعية تمثلت فيما يلي : 1- أمراض الطفل :

أوضحت النتائج البحثية فيما يتعلق بمكون أمراض الطفل أنه يوجد العديد من الأمراض المتعلقة بالطفل

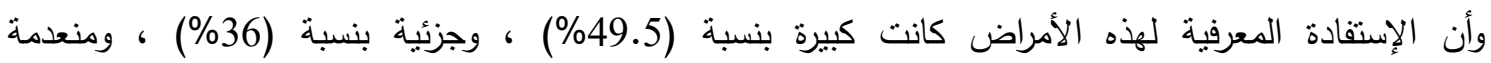
بنسبة(14.5\%) ، جدول رقم (12) ـ كما أوضحت النتائج البحثية أن أمراض الطفل تمثلت في نزلات البرد بنسبة

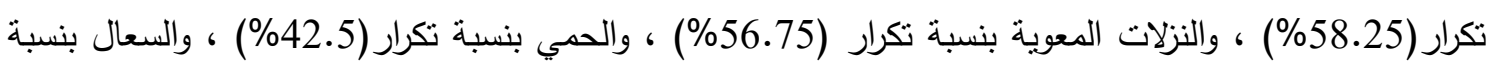

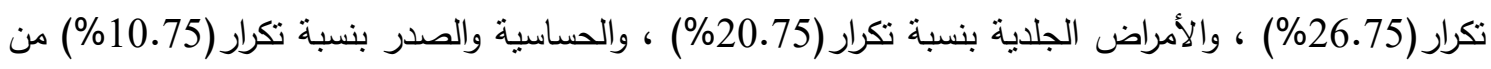

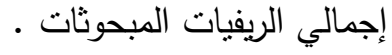
2- نطعيمات الطفل :

أوضحت النتائج البحثية فيما يتعلق بمكون تطعيمات الطفل أنه توجد العديد من التطعيمات والتي يأخذها

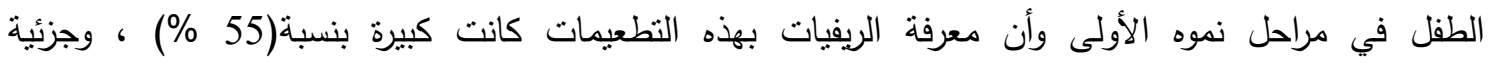
بنسبة(26.75\%) ، ومنعدمة بنسبة(18.25\%) ، جدول رقم (12) ـ كما أوضحت النتائج البحثية أن التطعيمات

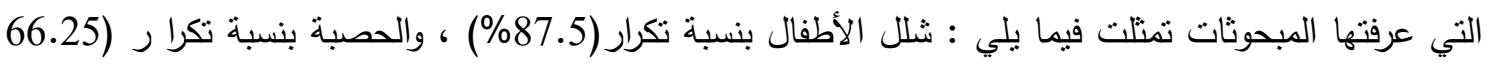

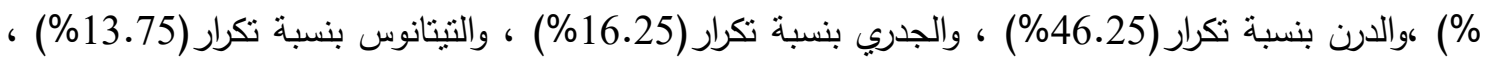
والإلتهاب الكبدي بنسبة تكرار (10.75\%) من إجمالي الريفيات المبحوثات . 3- العناية بالطفل: 
أظهرت النتائج البحثية فيما يتعلق بمكون العناية بالطفل أنه تعددت طرق العناية بالطفل ، حيث بلغت نسبة

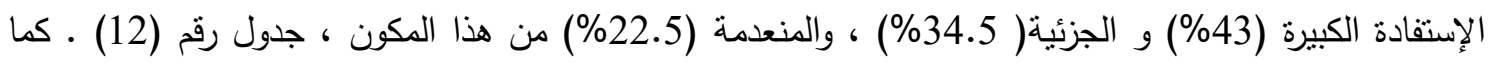

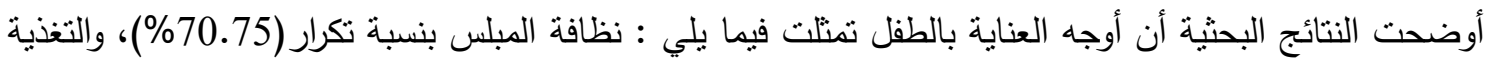

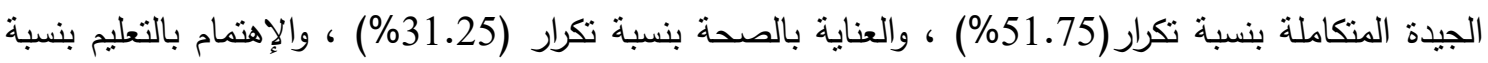

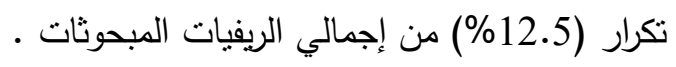

4- نغذية الطفل:

أبانت النتائج البحثية فيما يتعلق بمكون تغذية الطفل أنه تعددت طرق التغذية ، حيث بلغت نسبة الإستفادة

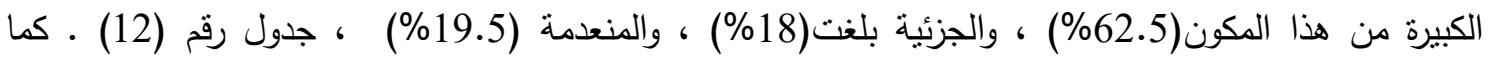
أوضحت النتائج البحثية أن تغذية الطفل تضمنت مجموعة من المواد الغذائية تمثلت فيما يلي : البيض بنسبة تكرار

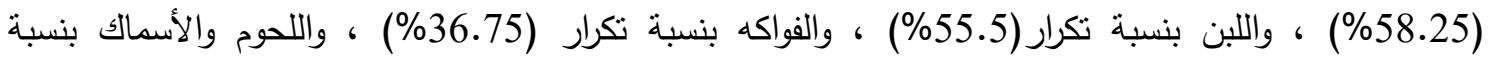

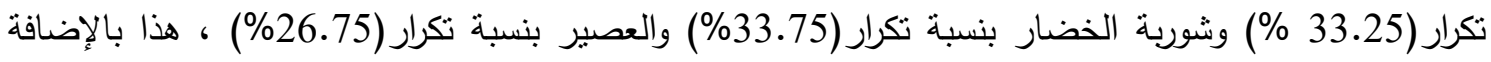

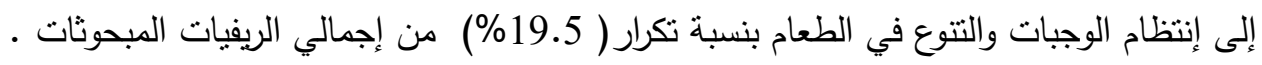

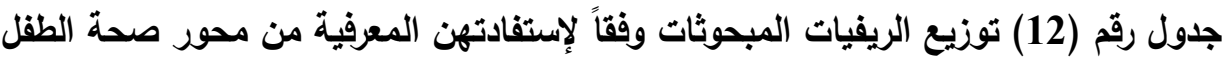

\begin{tabular}{|c|c|c|c|c|c|c|c|c|}
\hline \multirow{2}{*}{$\%$} & \multirow{2}{*}{ المجموع } & \multicolumn{2}{|c|}{ منعدمة } & \multicolumn{2}{|c|}{ جزئية } & \multicolumn{2}{|c|}{ كبيرة } & \multirow{2}{*}{ مكونات صحة الطُّلَ الإستفادة } \\
\hline & & $\%$ & العدد & $\%$ & العدد & $\%$ & العدد & \\
\hline 100 & 160 & 14.50 & 23 & 36.00 & 58 & 49.50 & 79 & أمر اض الطفل \\
\hline 100 & 160 & 18.25 & 29 & 26.75 & 43 & 55.00 & 88 & تطعيمات الطفل \\
\hline 100 & 160 & 22.5 & 36 & 34.50 & 55 & 43.00 & 69 & العناية بالطفل \\
\hline 100 & 160 & 19.50 & 31 & 18.00 & 29 & 62.50 & 100 & تغذية الطفل \\
\hline 100 & 160 & 18.75 & 30 & 28.75 & 46 & 52.50 & 84 & المتوسط العام للإستفادة \\
\hline
\end{tabular}

يتضح من الجدول السابق أن أكثر من نصف الريفيات المبحوثات(52.5\%) يتمتعن بإستفادة معرفية كبيرة

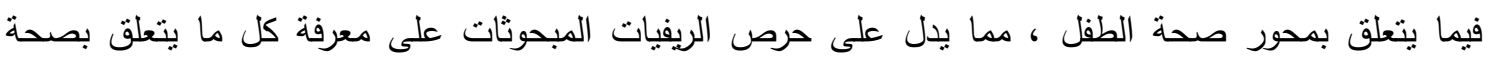
أطفالهن حتى يحافظن عليها ويتمتع أطفالهن بصحة جيدة ، مما يزيد من بهجتهن وإصرارهن على تلبية احتياجاتهن

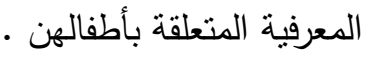
4- صحة الغذاء:

أوضحت النتائج البحثية فيما يتعلق بمحور صحة الغذاء أنه تناول العديد من النقاط تمثلت فيما يلي :

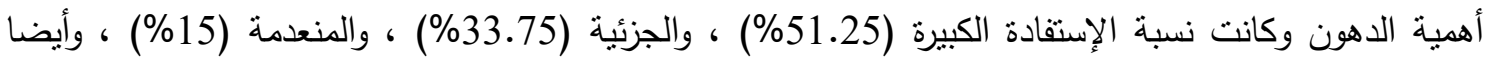

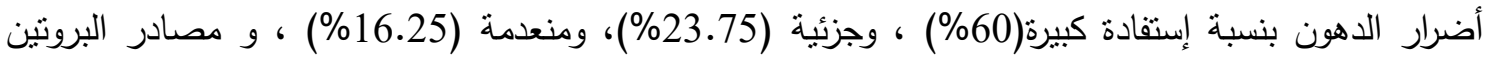
بنسبة إستفادة مرتفعة (60.5\%) ، وجزئية (23.75\%) ، ومنعدمة (15.75\%) ، هذا بإلإضافة إلى أهمية البروتين

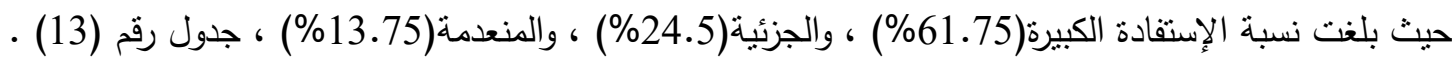

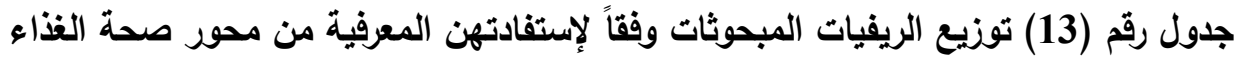

\begin{tabular}{|c|c|c|c|c|c|c|c|c|}
\hline \multirow{2}{*}{$\%$} & \multirow{2}{*}{ المجموع } & \multicolumn{2}{|c|}{ منعدمة } & \multicolumn{2}{|c|}{ جزئية } & \multicolumn{2}{|c|}{ كبيرة } & \multirow{2}{*}{ 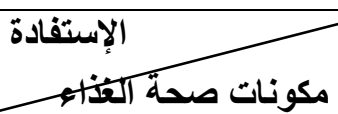 } \\
\hline & & $\%$ & العدد & $\%$ & العدد & $\%$ & العدد & \\
\hline 100 & 160 & 15.00 & 24 & 33.75 & 54 & 51.25 & 82 & أهمية الدهون \\
\hline 100 & 160 & 16.25 & 26 & 23.75 & 38 & 60.00 & 96 & أضر ار الدهون \\
\hline 100 & 160 & 15.75 & 25 & 23.75 & 38 & 60.50 & 97 & مصادر البروتين \\
\hline 100 & 160 & 13.75 & 22 & 24.50 & 39 & 61.75 & 99 & أهمية البروتين \\
\hline 100 & 160 & 15.00 & 24 & 26.75 & 43 & 58.25 & 93 & المتوسط العام للإستفادة \\
\hline
\end{tabular}

Vol. 20 (1), 2015 
يتضح من الجدول السابق أن أكثر من نصف الريفيات المبحوثات (58.25 \%) تمتعن بإستقادة معرفية

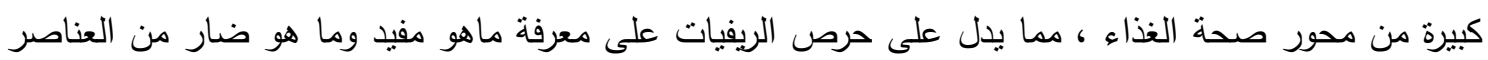
الغذائبة المختلفة وذلك لتجنب الأضرار والإستفادة من الفوائدعند تحضير الوجبات الغذائية . 5- 5 - 5 التغنية العلاجية :

أوضحت النتائج البحثية فيما يتعلق بمحور التغذية العلاجية أنه قد إنتمل على كيفية التغذية في حالة

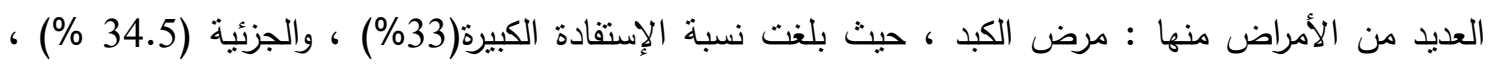

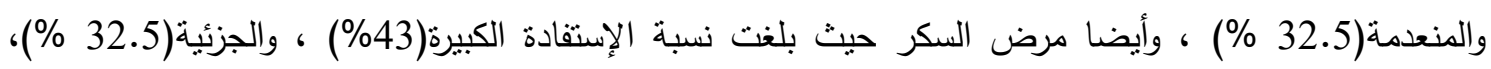

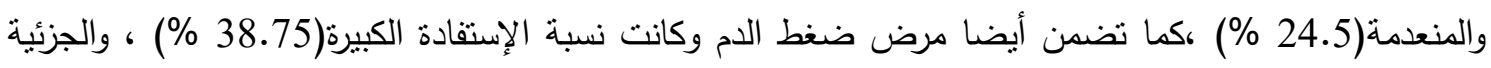

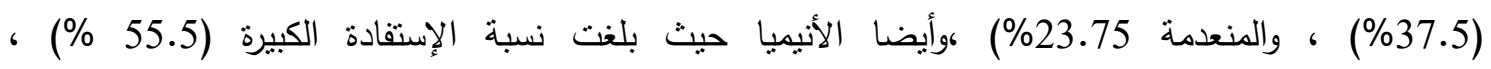
والجزئية(20\%)، والمنعدمة(24.5 \% \%)، هذا بالإضافة إلى تغذية كبار السن حيث بلغت بلثة نسبة الإستفادة

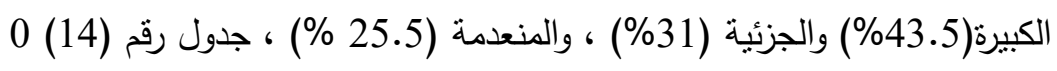

جدول رقم (14) توزيع الريفيات المبحوثات وفقا لإستفادتهن المعرفية من محور التغذية ولندات العلاجية

\begin{tabular}{|c|c|c|c|c|c|c|c|c|}
\hline \multirow{2}{*}{$\%$} & \multirow{2}{*}{ المجموع } & \multicolumn{2}{|c|}{ منعدمة } & \multicolumn{2}{|c|}{ جزئية } & \multicolumn{2}{|c|}{ كبيرة } & \multirow[t]{2}{*}{ الإستفادة } \\
\hline & & $\%$ & العدد & $\%$ & العدد & $\%$ & العدد & \\
\hline 100 & 160 & 32.50 & 52 & 34.50 & 55 & 33.00 & 53 & مرض الكبد \\
\hline 100 & 160 & 24.5 & 39 & 32.50 & 52 & 43.00 & 69 & مرض السكر \\
\hline 100 & 160 & 23.75 & 38 & 37.50 & 69 & 38.70 & 62 & ضغط الدم \\
\hline 100 & 160 & 24.50 & 39 & 20.00 & 32 & 55.50 & 89 & الأنيميا \\
\hline 100 & 160 & 25.50 & 41 & 31.00 & 50 & 43.50 & 69 & كبار السن \\
\hline 100 & 160 & 26.25 & 42 & 31.25 & 50 & 42.50 & 68 & المتوسط العام للإستفادة \\
\hline
\end{tabular}

يتضح من الجدول السابق أن(42.5 \% من الريفيات المبحوثات تتمتعن بإستفادة معرفية كبيرة من محور التغذية العلاجية ، مما قد يؤكد على أهمية هذا المحور ، حيث أن الريفيات يحرصن على معرفة كيف تتم التغذية في الحالات المرضية المختلفة ، مما يساعدهن على الحفاظ على صحتهن وصحة أفراد أسرهن . 6

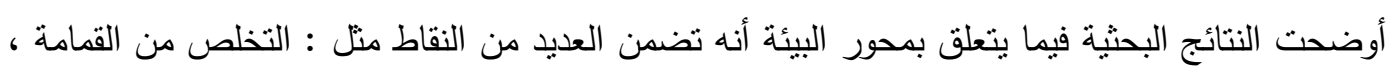

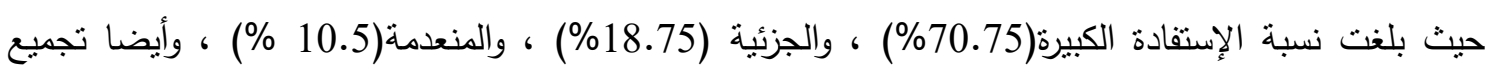

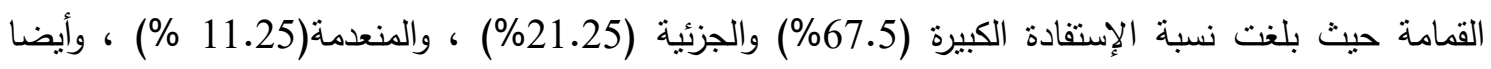

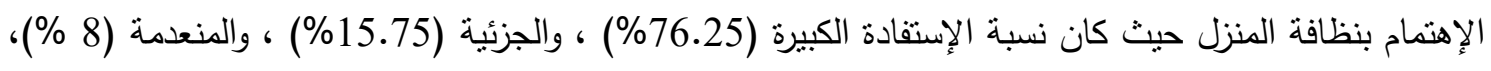

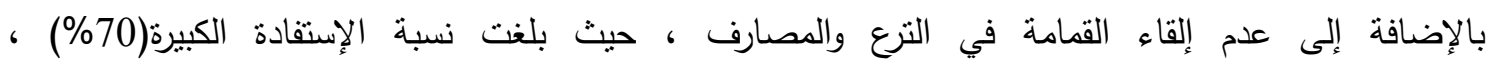
والجزئية(18.25\%) ، والمنعدمة (11.75 \%) ، وأيضا كيفية القضاء على الحشرات المنزلية حيث بلغت نسبة الإسة

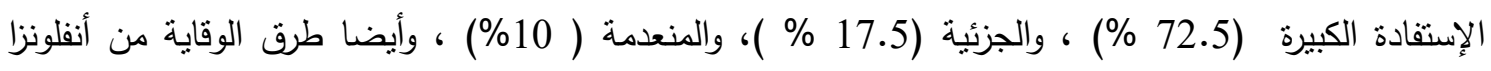

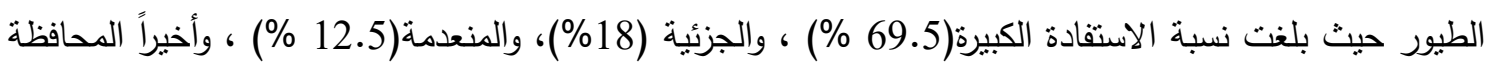

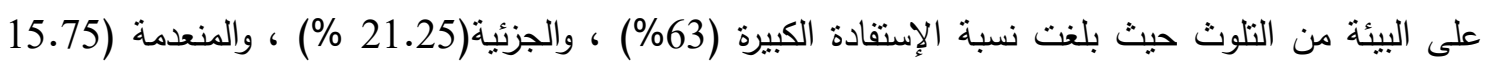

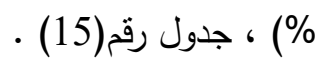


جدول رقم (15) توزيع الريفيات المبحوثات وفقاً لإستفادتهن المعرفية من محور البيئة

\begin{tabular}{|c|c|c|c|c|c|c|c|c|}
\hline \multirow[b]{2}{*}{$\%$} & \multirow[b]{2}{*}{ المجموع } & \multicolumn{2}{|c|}{ منعدمة } & \multicolumn{2}{|c|}{ جزئية } & \multicolumn{2}{|c|}{ كبيزة } & \multirow[t]{2}{*}{ 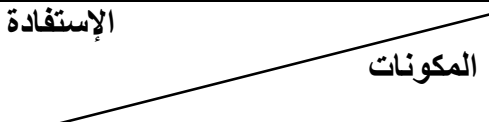 } \\
\hline & & $\%$ & العدد & $\%$ & العدد & $\%$ & العدد & \\
\hline 100 & 160 & 10.5 & 17 & 18.75 & 30 & 70.75 & 113 & التخلص من القمامة المنزلية \\
\hline 100 & 160 & 11.25 & 18 & 21.25 & 34 & 67.5 & 108 & تجميع القمامة \\
\hline 100 & 160 & 8.00 & 13 & 15.75 & 25 & 76.25 & 122 & الإهتمام بنظافة المنزل \\
\hline 100 & 160 & 11.75 & 19 & 18.25 & 29 & 70.00 & 112 & عدم إلقاء القمامة في التر ع و المصارف \\
\hline 100 & 160 & 10.00 & 16 & 17.5 & 28 & 72.50 & 116 & كيفية القضاء على آلحشر ات المنزلية \\
\hline 100 & 160 & 12.5 & 20 & 18.00 & 29 & 69.50 & 111 & طرق الوقاية من انفلونز ا الطيور \\
\hline 100 & 160 & 15.75 & 25 & 21.25 & 34 & 63.00 & 101 & المحافظة على البيئة من التلوث \\
\hline 100 & 160 & 11.25 & 18 & 18.75 & 30 & 70.00 & 112 & المتوسط العام للإستفادة \\
\hline
\end{tabular}

يتضح من الجدول السابق أن غالبية الريفيات المبحوثات (70\%) تتمتعن بمستويات معرفية كبيرة وذللك فيما

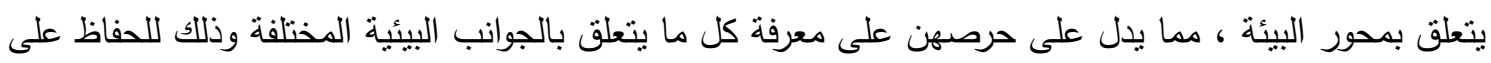

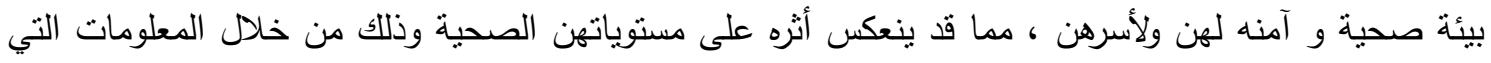

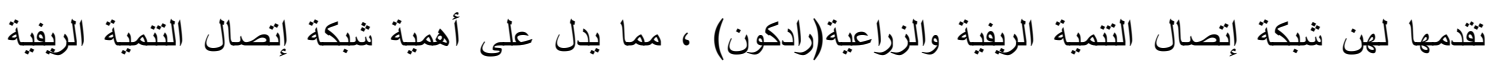

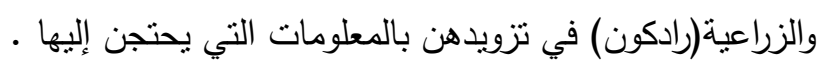

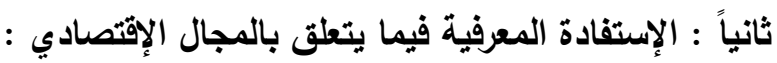

وينطوى هذا المجال على محور رئيسي يتمنل في المشروعات الصغيرة التي يمكن أن تسهم في تحسين الإسئنس دخل الريفيات المبحوثات وبالتالي النهوض بمسنوياتهن المعيشية ، وذللك كما يلي : المشروعات الصغيرة : الصغئ أوضحت النتائج البحثية فيما يتعلق بمحور المشروعات الصغيرة ، أن شبكة إتصال التتمية الريفية والزراعية

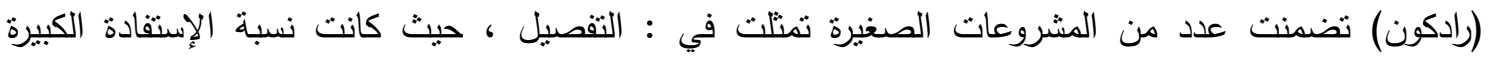

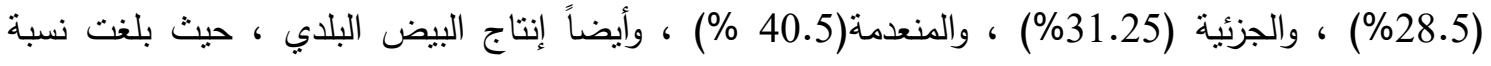

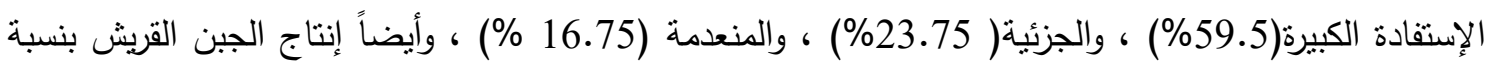

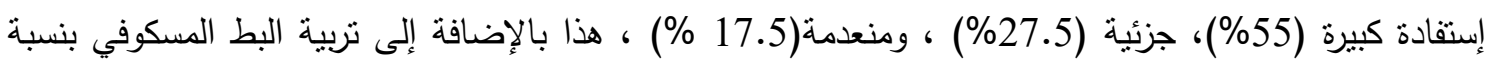

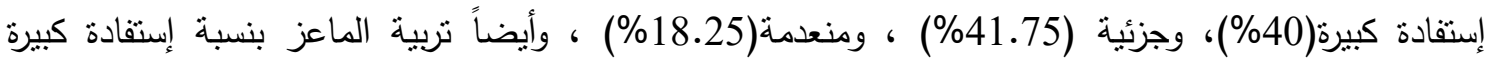

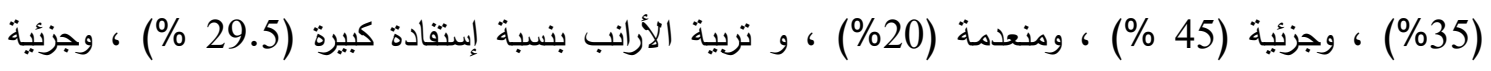

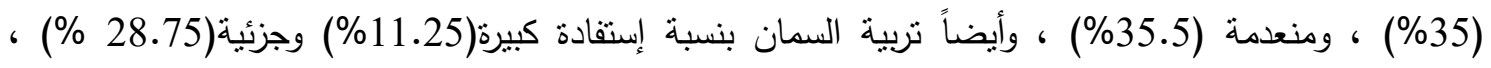

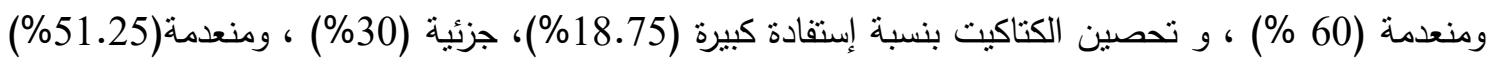

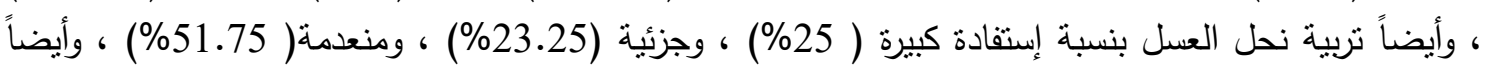

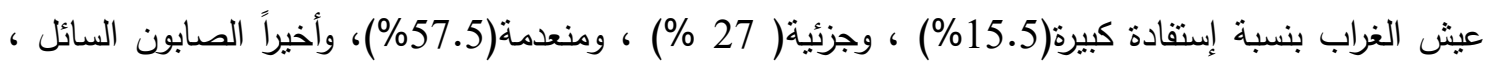

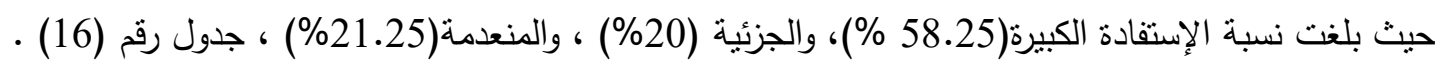




\begin{tabular}{|c|c|c|c|c|c|c|c|c|}
\hline \multirow{2}{*}{$\%$} & \multirow{2}{*}{ المجموع } & \multicolumn{2}{|c|}{ منعدمة } & \multicolumn{2}{|c|}{ جزئية } & \multicolumn{2}{|c|}{ كبيرة } & \multirow{2}{*}{ المشروعـات الإستفادة } \\
\hline & & $\%$ & العدد & $\%$ & العدد & $\%$ & العدد & \\
\hline 100 & 160 & 40.50 & 6 & 31.25 & 50 & 28.35 & 45 & التفصبل \\
\hline 100 & 160 & 16.75 & 27 & 23.75 & 38 & 59.50 & 95 & إنتاج البيض البلدي \\
\hline 100 & 160 & 17.50 & 28 & 27.5 & 44 & 55.00 & 88 & إنتاج الجبن القريش \\
\hline 100 & 160 & 18.25 & 29 & 41.75 & 67 & 40.00 & 64 & تربية البط المسكوفي \\
\hline 100 & 160 & 20.00 & 32 & 45.00 & 72 & 35.00 & 56 & تربية الماعز ت \\
\hline 100 & 160 & 35.50 & 57 & 35.00 & 56 & 29.50 & 47 & تربية الأر انب \\
\hline 100 & 160 & 60.00 & 96 & 28.75 & 46 & 11.25 & 18 & تربية السمان \\
\hline 100 & 160 & 51.25 & 82 & 30.00 & 48 & 18.75 & 30 & تحصين الكتاكيت \\
\hline 100 & 160 & 51.75 & 83 & 23.25 & 37 & 25.00 & 40 & تربية نحل العسل \\
\hline 100 & 160 & 47.50 & 92 & 27.00 & 43 & 15.50 & 25 & عيش الغراب \\
\hline 100 & 160 & 21.25 & 34 & 20.50 & 33 & 58.25 & 93 & الصـابون السائل \\
\hline 100 & 160 & 83.75 & 134 & 3.50 & 5 & 13.00 & 21 & مشرو عات أخرى \\
\hline 100 & 160 & 40.5 & 65 & 28.25 & 45 & 31.25 & 50 & المتوسط العام للإستفادة \\
\hline
\end{tabular}

يتضح من الجدول السابق أن أكثر من نصف الريفيات المبحوثات (59 \%) تتمتعن بإستفادة معرفية كبيرة

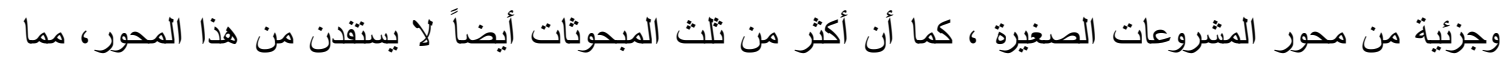

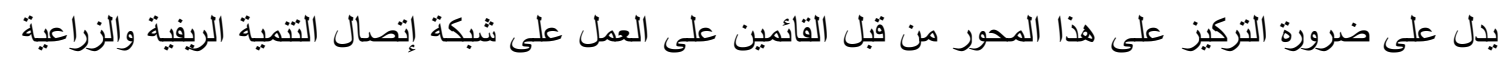

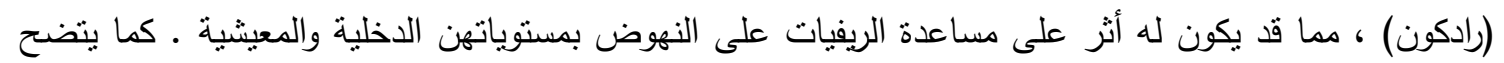

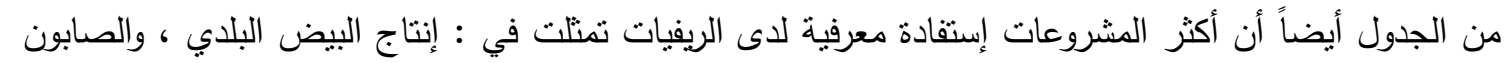
السائل وإنتاج الجبن القريش ، وذلك بالنسبة التالية لكل منهم على الترتيب (59.5 \%) ، و (58.25 \% . $(\%$

كما يتبين أيضاً أن هناك عدد من المشروعات كانت إستفادة المبحوثات منها منعدمة وتمنلت في : نربية

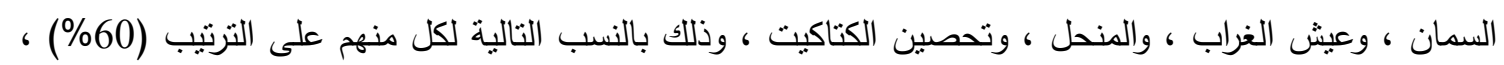

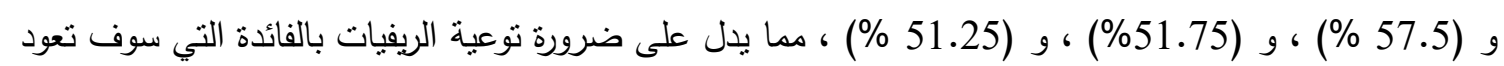
عليهن من منل هذه المشروعات نظراً للعائد المجزي الذى سوف يعود عليهن منها ـ ـ كما أظهرت النتائج أيضاً

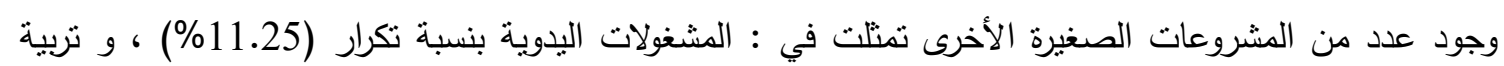

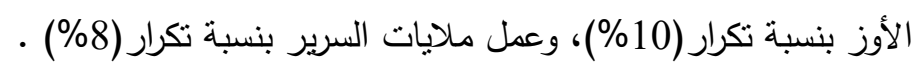

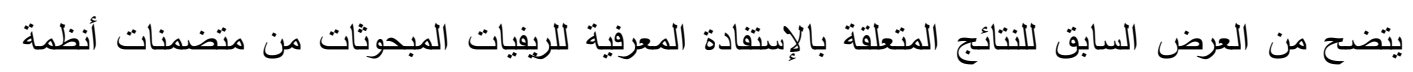

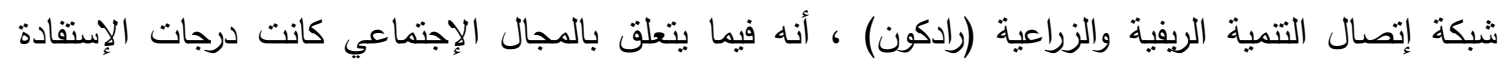

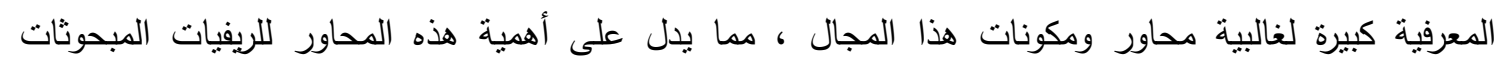

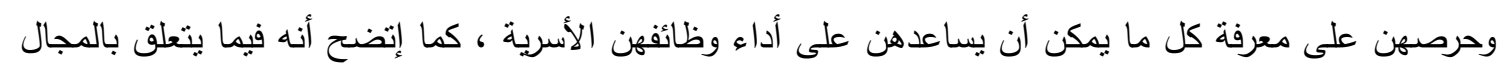

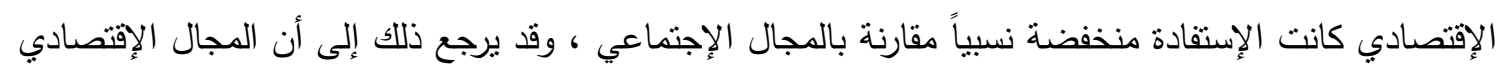

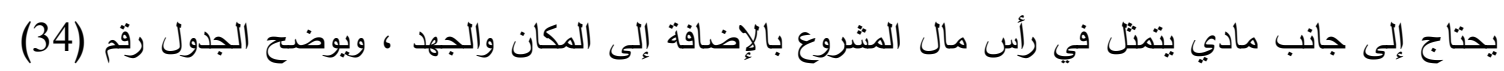
تلخيصاً لمستوى الإستفادة المعرفية من المجالات المتضمنة بأنظمة شبكة إتصال التتمية الريفية والزراعية 
جدول رقم (17) توزيع الريفيات المبحوثات وفقاً للمتوسط العام لمستوى الإستفادة المعرفية من المجالات

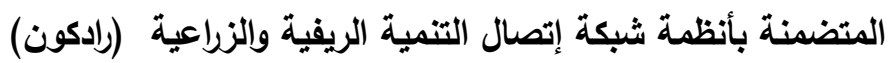

\begin{tabular}{|c|c|c|c|c|c|c|}
\hline \multicolumn{2}{|c|}{ منعدمة } & \multicolumn{2}{|c|}{ جزئية } & \multicolumn{2}{|c|}{ كبيرة } & \multirow{2}{*}{ المجالات التموية الإستثادة } \\
\hline$\%$ & العدد العد & $\%$ & 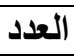 & $\%$ & العدد & \\
\hline 3450 & 55 & 1950 & 31 & 4600 & 74 & 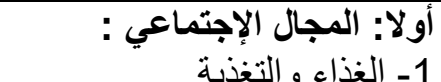 \\
\hline 23.25 & 37 & 26.00 & 42 & 50.00 & 81 & 2- صحة المر أة \\
\hline 18.75 & 30 & 28.75 & 46 & 52.50 & 84 & 3- صحة الطفل \\
\hline 15.00 & 24 & 26.75 & 43 & 58.25 & 93 & 4- صحة الغذاء \\
\hline 26.25 & 42 & 31.25 & 50 & 42.50 & 68 & 5- التغذية العلاجية \\
\hline 11.25 & 18 & 18.75 & 30 & 70.00 & 112 & 6- البيئـة \\
\hline & & & & & & ثانيا: المجال الاقتصادي: \\
\hline 40.50 & 65 & 28.25 & 45 & 31.25 & 50 & ـ المشرو عات الصغيرة \\
\hline 27.5 & 44 & 23.75 & 38 & 48.75 & 78 & المتوسط العام للإستفادة \\
\hline
\end{tabular}

يتضح من الجدول السابق أن أكثر المحاور إستفادة بالنسبة للريفيات المبحوثات ، تمنلت فى البيئة بنسبة

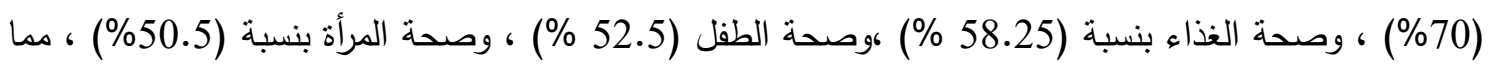

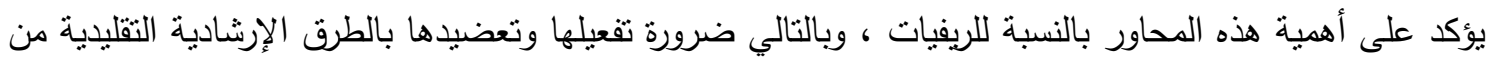

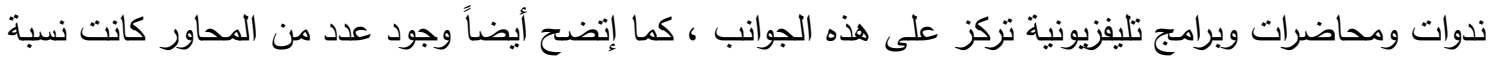

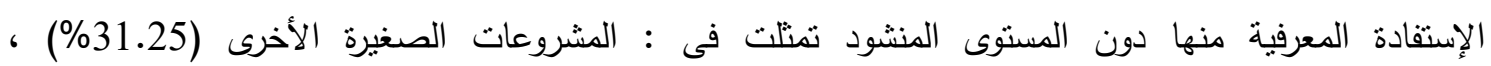

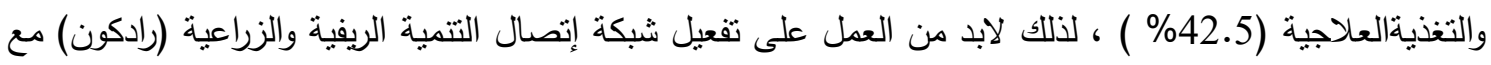
التركيز على هذه الجوانب وتفعيل متضمناتها و تعضيدها حتى تتمكن الريفيات من الحصول على أقصى إستفادة

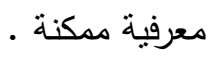
ثالثا: العلاقات الإرتباطية والإنحدارية المتعددة بين مستوى الإستفادة المعرفية للريفيات المبحوثات ويين المتغيرات المستقلة المدروسة:

تتثير البيانات الموضحة بالجدول رقم (18) إلى وجود وجود علاقة إرتباطية موجبة مغزوية بين مستوى

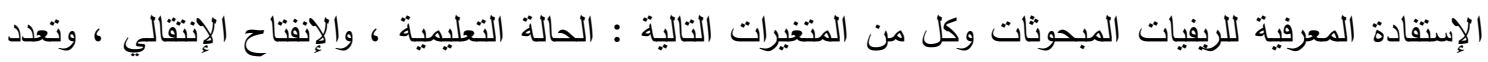

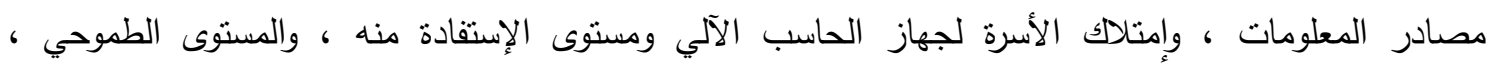
والتجدية ، ومستوى التعرض للثبكة ، والمعرفة بأنظمة الثبكة ، والرضا عن الثنبكة ، والمسنوى الثقييمي الثيني لخصائص محتوى الثبكة . وتبين أيضاً عدم وجود علاقة إرتباطية مغزوية بين مستوى الاستفادة المعرفية للريفيات المبحوثات وكل من المتغيرات التالية ( السن ، والحالة الإجتماعية ، والتجددية ، والحيازة الأرضية المزرعية عندية ألي منئية من المستوبين

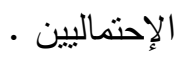


جدول رقم (18) قيم معاملات الارتباط البسيط بين مستوى الإستفادة المعرفية من متضمنات أنظمة

الثبكة والمتغيرات المستقبلية المدروسة

\begin{tabular}{|c|c|c|c|}
\hline الارتباط & المتغيرات & الارتباط & المتغيرات \\
\hline ** 0.198 & التجددية & $0.066-$ & السن \\
\hline 0.023 & الحبازة الأرضية المزر عية & * 0.285 & الحالة التعليمية \\
\hline 0.063 & القيادية & 1.641 & 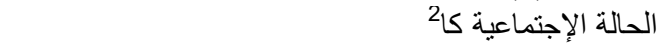 \\
\hline * 0.286 & 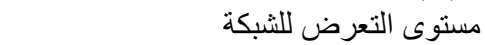 & * 0.322 & الإنفتاح الإنتقالي \\
\hline * 0.525 & المعرفة بانظمة الثبكة & $\underset{*}{0.310}$ & تعدد مصنادر المُعلومات \\
\hline * 0.648 & الرضا عن الثبكة & * 0.325 & إمتلاك الأسرة لجهاز الحاسب الآلي ومستوى الإستفادة منها \\
\hline * 0.610 & المستوى التقبيمي لخصائص محتوى الثبكة & * 0.253 & المستوى الطموحي \\
\hline \multirow{2}{*}{\multicolumn{3}{|c|}{$4={ }^{2} \leq$}} & " مستوى الدلالة الإحصائية (0.01 ) \\
\hline & & & *** مستوى الدلالة الإحصائية (0.05) \\
\hline
\end{tabular}

تحقيق الفرض البحثي الأول : في ضوء نتائج التحليل الإرتباطي البسيط فإنه يرفض الفرض الإحصائي

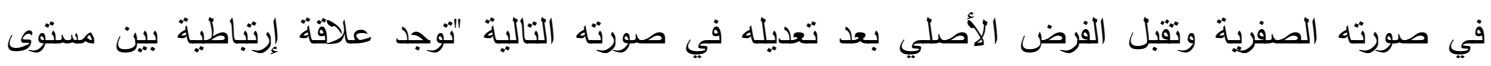
الاستفادة المعرفية للريفيات المبحوثات من متضمنات أنظمة شبكة الاتصال (رادكون) والمتغيرات التالية : الحالة

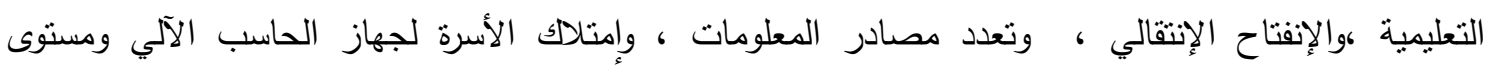

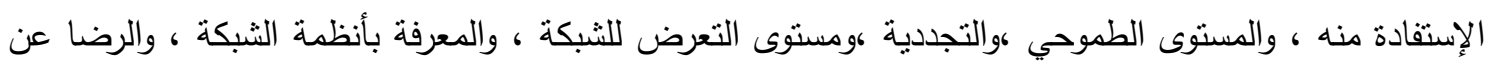
الثبكة ، والمستوى النقييمي لخصائص محتوى الثبكة .

\section{العلاقة الإنحدارية الذطية المتعددة بين متغيرات الاراسية :}

في ضوء العلاقات الإرتباطية اتجهت الدراسة إلى تقدير تأثنير المتغيرات المستقلة على التئل التباين الحادث في مستوى الإستفادة المعرفية للريفيات المبحوثات من متضمنات أنظمة شبكة إتصال التتمية الريفية والزراعية (رادكون)

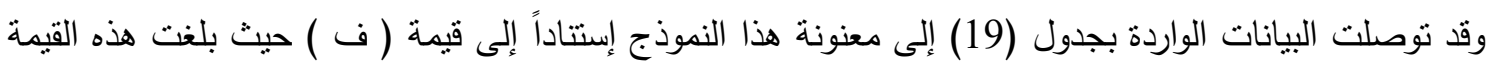

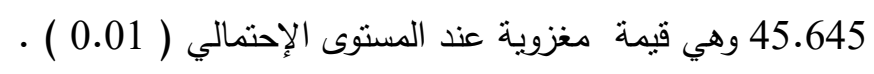
جدول رقم (19) العلاقة الإنحدارية الخطية بين مستوى الإستفادة المعرفية من متضمنات أنظمة شبكة إتصال

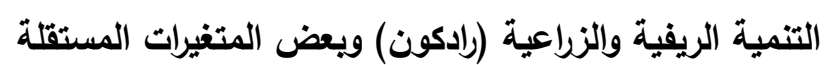

\begin{tabular}{|c|c|c|c|c|}
\hline التأثيرتيب & معامل الآحدار الجزئي & 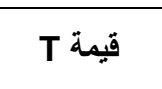 & معامل الانحدار & المتغيرات \\
\hline الأول & 0.405 & ** 5.309 & 2.155 & الرضـا عن الثبكة \\
\hline الثاني & 0.233 & ** 4.320 & 3.910 & تعدد مصادر المعلومات \\
\hline 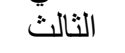 & 0.202 & ** 3.363 & 3472 & المعرفة بأنظمة الثبكة \\
\hline الر ابع & 0.214 & ** 2.817 & 1.817 & المستوى التقبيمي لخصائص محتوى الثبكة \\
\hline 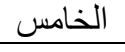 & 0.112 & * 2.158 & 1.402 & التجددية \\
\hline \multicolumn{3}{|c|}{$* * 45.645=\mathrm{F}$} & \multicolumn{2}{|r|}{$0.584=\mathrm{R} 2$} \\
\hline
\end{tabular}

وتثير البيانات الواردة بالجدول إلى أن المتغيرات المستقلة الخمس وهي : متغير تعدد مصادر المعلومات ، ومتغير التجديدية ، ومتغير المعرفة بأنظمة الثبكة ، ومتغير الرضا عن الثبكة ،و متغير المسنوى الثقييمي لخصائص محتوى الشبكة ، مجتمعة تفسر حوالي 58\% من التباين الحادث في مستوى الإستفادة المعرفية للريفيات 
المبحوثات وهي نسبة كبيرة تشير إلى إسهام المتغيرات المدروسة إسهامًا قوياً في تفسير التباين في مستوى الإستفادة المعرفية لمتضمنات أنظمة الثبكة 0 تحقيق الفرض البحثي الثناني : في ضوء نتائج التحليل الإنحداري الجزئي القياسي فإنه يرفض الفرض الإحصائي في صورته الصفرية وتقبل الفرض الأصلي بعد تعديله في صورته التالية "بتأثير مستوى الاستفادة

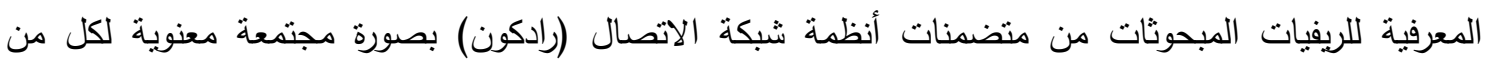

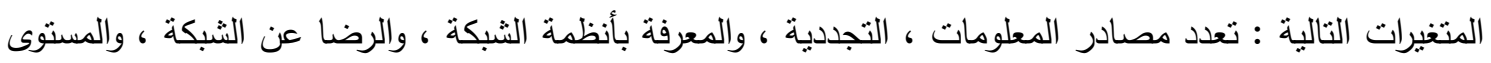

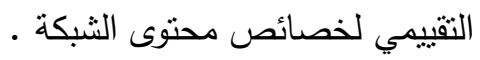
رابعاً : المشكلات التي تواجه الريفيات المبحوثات عند الإتصال بشبكة إتصال التنمية الريفية والزراعية (رادكون) والحلول المقترحة من وجهة نظرهن :

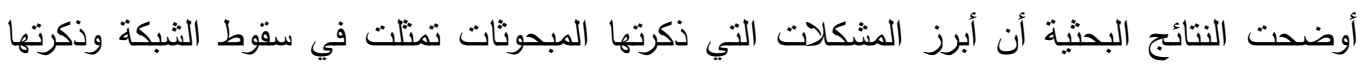
(31.75\%) من المبحوثات ، وعطل الكمبيوتز (22.5\%) من المبحوثات ، وأن المعلومات على الثبكة قليلة وغير لكير مناسبة لحجم الأنظمة والموضوعات المطروحة عليها (16.25\%) من المبحوثات ، في حين تمنلت أبرز الحلول المقترحة من وجهة نظرهن في : حل مشكلات الثبكة وتدعيم الانترنت وذكرتها (31.75\%) من المبحوثات ،وصيانة وإصلاح الكمبيوتر وذكرتها (22.5\%) من المبحوثات ، وزيادة المعلومات على الأنظمة وذكرتها

إستخلاصاً لما آلت إليه نتائج هذا البحث فإنها توصي بما يلي :

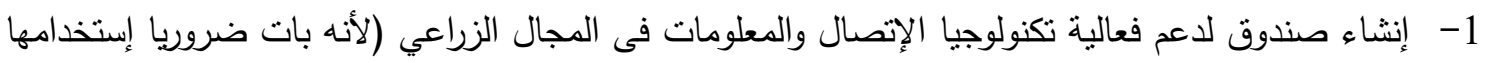

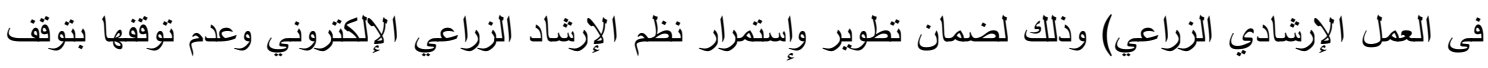

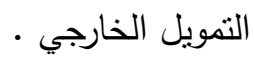

2- تحديث الحاسبات الآلية وملحقاتها بالمراكز الإرشادية الزراعية مع توفير أجزة لاب توب حتى يمكن حملها

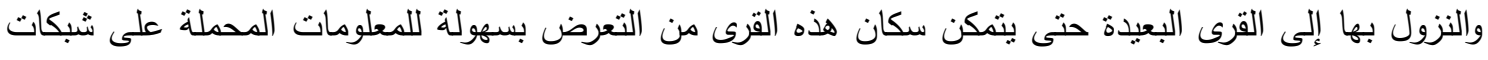

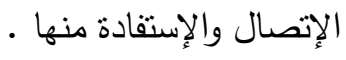
3- توفير الحوافز المادية والمعنوية للقائمين بالعمل الإرشادي بالمراكز الإرشادية .

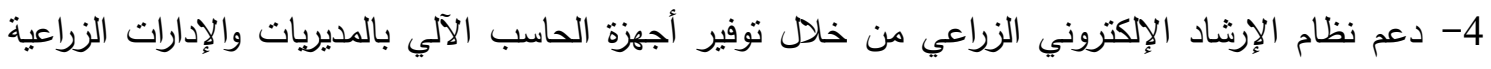

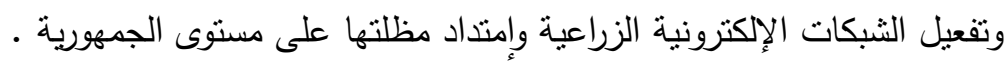

المراجع المراجع العربية : المراجم إبراهيم ، الاسوقى عبده ـ 2004 ـ وسائل وأساليب الإتصال الجماهيرية والإتجاهات الإجتماعية تحليل نظرى.دار

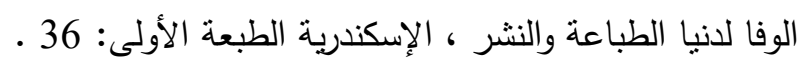
البندارى ، صفاء أحمد فهيم 2005. دراسة واقع ومستقبل شبكة إتصال البحوث والإرشاد (فيركون) كسبيل لتحديث طرق الإتصال الإرشادى ، دراسة حاله فى بعض القرى بمحافظة كفر الثيخ · رسالة دكتوراه ، كلية الزراعة ، جامعة الإسكندرية : 6 . 
الذهبى ، أحمد محمد و عبد العليم أحمد الثافعى . 2012 ـ تعرض الريفيات لشبكة إتصال التتمية الريفية والزراعية (رادكون) وإستفادتهن من نظام المرأه ببعض قرى محافظة كفر الثيخ مجلة الجمعية العلمية للإرشاد الزراعى ، مجلد 16 ، العدد 427 الصياد ، عبد الباسط ـ 2008 ـ الإتصال بالمشاركة وإدارة وتطوير المحتوى ـ وحدة الملومات والإتصال من أجل التنمية ، معهد بحوث الإرشاد الزراعى والتتمية الريفية : 19 ـ 19 النحاس ، محمود عبد السلام .2011 ـ الإستفادة من النظام الخبير للقمح بالمراكز الإرشادية الزراعية بمحافظة

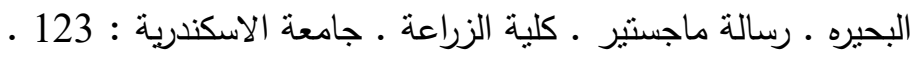

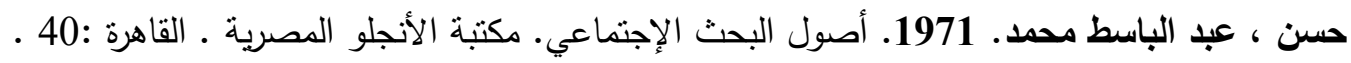

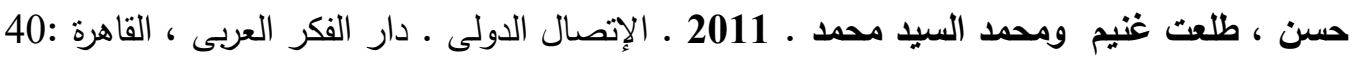
حسيب ، هيام محمد عبد المنعم و صفاء أحمد فهيم البندارى ـ 2010 ـ معارف الريفيات بأنظمة شبكة إتصال التتمية الريفية والزراعية (رادكون) ،و تعاملهن مع نظام المرأه ومردوده عليهن ببعض قرى ملئ محافظة البحيره ـ مجلة العلوم الإقتصادية والاإجتماعية ، مجلد 1 ، عدد 5 : 392 . حلمي ، أحمد فؤاد .1990 ـ دراسة الإحتباجات التعليمية الإرشادية للزراع في مجال التسميد وصيانة التربة بمنطقة إمتداد أبيس محافظة الإسكندرية ـ رسالة ماجستير ، كلية الزراعة جامعة الإسكندرية: 35 ـ

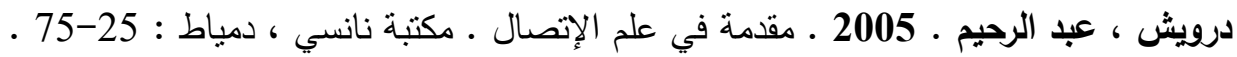
سالم ، مروه السيد عبد الرحيم 2013. دورة متقدمة فى الإتصال . دورة تدريبية بمعهذ بحوث الإششاد الزراعي والتتمية الريفية ، فرع الإسكندرية : 9 .

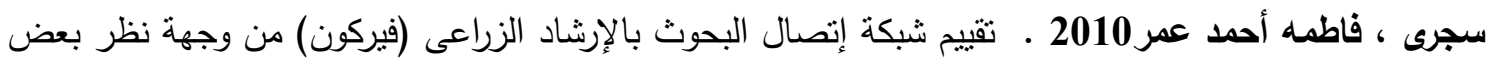
الأخصائيين الزراعيين مسئولي الثبكة بالمراكز الإرشادية ـ رسالة دكتوراه. كلية الزراعة جامعة القاهره : 136 شاكر ، محمد حامد ذكى وزكريا محمد الزرقا و حسن على حسن شرشر. 2004. الاثز الإرشادى لتعرض الزراع لنظام المشكلات وتتبع حلولها بشبكة الفيركون بمحافظة كفر الثيخ . مجلة جامعة المنصوره للعلوم الإجتماعية ، مجلد 29 ، عدد 11 :6341.

شاكر ، محمد حامد ذكى 2008 ـ إستخدام تكنو لوجيا المعلومات والإتصال فى العمل الإرشادي الريفي . فى ،

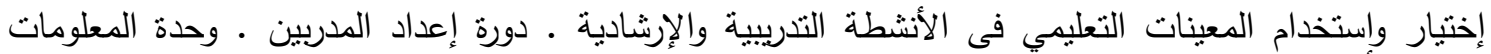
والإتصال من أجل التتمية ـ معهد بحوث الارشاد الزراعى والتتمية الريفية : 52 . شبانه ، رشا محمد السيد . 2010." دراسة تقييمية لنظام مشكلات المزارعين على شبكة إتصال البحوث بالإرشاد الزراعى " رسالة ماجستير ، كلية الزراعة جامعة المنصوره : 41 . شبانه ، لؤى. 2009. تكنولوجيا المعلومات والإتصالات ودورها فى رسم المستقبل المستدام ـ المؤتمر الإحصائى لرعي العربى ، طرابلس الجماهيرية العربية الليبية الثعبيى الإشتراكية العظىى ، 2-4 /نوفمبر /2009 : 1 . طلبه ، ليلى أنور و هيام محمد عبد المنعم حسيب وشفيقه عبد المنعم محمد 2001 ـ ـ دراسة مدى إسهام المرأه

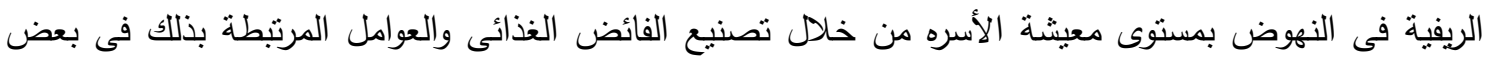
قرى محافظتى الإسكندرية والبحيرة . مجلة الإسكندرية للتبادل العلىى ، عدد 3 مجلد 22: 214. عاصم ، خلود ومحمد إبراهيم. 2013. دور تكنولوجيا المعلومات والإتصالات فى تحسين جودة المعلومات

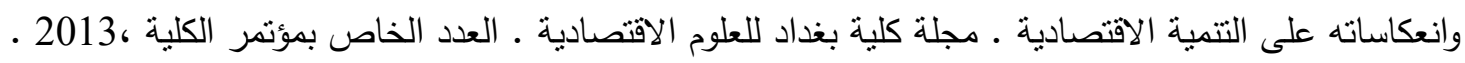


عبد المجيد ، محمد عبد المجيد محمد ومحمد حسن قاسم رشا السيد شبانة .2011 ـ دراسة تقييمية لنظام مشكلات الزراع وتتبع حلولها على شبكة إتصال البحوث والإرشاد الزراعي (فيركون) ـ. المجلة الزراعية للعلوم

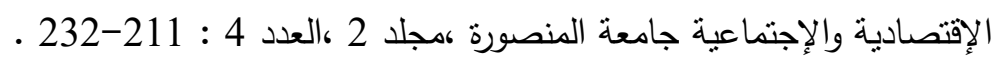
عبد الواحد ، منصور أحمد محمد حفنى و عبد المنعم محمد عبد الرحمن. 2010 ـ دراسة مستوى معرفة

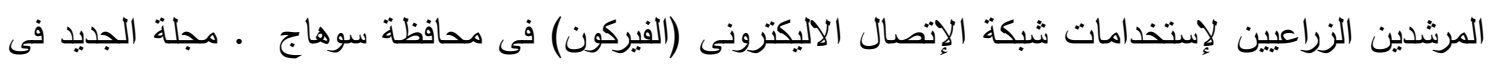

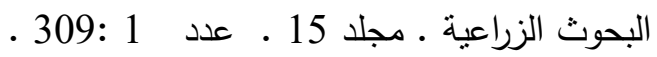

فتحي ، شادية حسن و محمد فتحي الثاذلي و سمير عبد العظيم عثمان و مجدي عبد الوهاب خطاب 2005 .

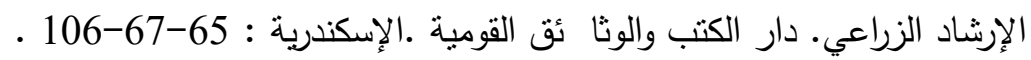
فتحي ، شادية حسن. 2009. التعليم المستمر ودوره فى التتمية البشرية ـ منشأة المعارف بالإسكندرية ـ الطبعة الأولى :45.

قاسم ،محمد حسن مصطفى . 2007 ـ تحليل قاعدة بيانات نظام مشكلات الزراع على شبكة إتصال البحوث والإرشاد للتعرف على قدرة الباحثين والأخصائيين والمرشدين على حل مشكلات الزراع بجمهورية مصر العربية . مجلة جامعة المنصوره ، مجلد 32 ، العدد 9 : 7940 . قثطه ، عبد الحليم عباس. 2012 ـ الإرشاد الزراعى رؤيه جديده ـ كلية الزراعة جامعة القاهره: 96-99. مكاوى ، حسن عماد. 2009. نظريات الإعلام ـ الدار العربية للنشر والتوزيع ـ الطبعة الأولى 0 القاهرة : 153 مهنا ، محمد نصر.2007 .الإعلام وتكنولوجيا الإتصال فى عالم متغير · مركز الإسكندرية للكتاب ، الطبعة الثنانية 0 الإسكندرية 700 نصر الله ، عمر عبد الرحيم. 2010. مبادىء الاتصال التربوى والإنسانى ـ دار وائل للنشر والتوزيع ،الأردن عمان ، الطبعة الثانية :31 . هيكل ، وائل على محمود .2012 ـ فعالية النظام الخبير لمحصول الأرز فى العمل الإرشادي بمحافظة كفر الثشخ .رسالة ماجستير . كلية الزراعة .جامعة الأزهر 0 القاهره : 98 .

واكد ، شرين ماهر و عزه عبد الكريم الجزار. 2012 ـالأثر التعليمى لندوة التتقيف الغذائى المحملة على شبكة الرادكون • مجلة العلوم الإقتصادية والإجتماعية الزراعية ، جامعة المنصوره كمجلد 3 ، العدد 4 : 6435.

\section{المراجع الإنجليزية :}

Cronkhite . G. . 1976 . Communication and awareness. Cumming Publishing Company menlopark . California . USA:7

Gamble, T. and GM. Chael . 2010 . Communication works New York . Inistitute of technology. Mc.braw .HiH. Gifts :9.

Blake , R.H. and E.O. Haroldsen. 1975. Ataxonomy of concepts in communication. Housting house .New york :35 . 


\title{
Level of Knowledge Benefit of Rural Women from Included of Rural and Agricultural Development Communication Network (RADCON) in Some Villages of El-Behera Governorate
}

\author{
Abo Zaid Mohamed Mohamed El -Habbal. Gamal Hussen Bekheit Amer. \\ Souzan Ibrahim El- Sayed El -Sharbatly and Hanan Nageib Ali Tahawy \\ Faculty of Agriculture. Saba Bacha . Alexandria University. \\ ${ }^{*}$ Agriculture Extension and Rural Development Research Inistitute .ARC .
}

ABSTRACT: The study aimed to determine the level of knowledge benefit of rural women from included Rural and Agriculture Development Communication Net work (RADCON). A questionnaire through personal interview was to collect data for this study from 160 respondent . statistical methods for analyzing research data including : mean, standard deviation, simple coloration coefficient, analysis of variance. Important findings could be summarized as follows .

1- Knowledge benefit level was about (16.25\%) of included RADCON was low , and $(66.75 \%)$ has moderate level, while $(17 \%)$ had high level .

2- The results showed that there was significant relationship between level of knowledge benefit and each of the following variables : educational status ,ambition level, the openness transitional ,the innovativeness, sources of information, owning the computer and level of benefit of it. the level of keeping on contact with RADCON, the knowledge about the Net work system of RADCON , satisfaction with RADCON, and evaluation level for the characteristics of the Net work content .

3- The results showed that multiple sources of information, the innovativeness , the knowledge about the Net work system of RADCON and satisfaction with RADCON, and evaluation level for the characteristics of the Net work content as independent variables have explained the variance in the knowledge benefit for the respondent of the included of RADCON .

4- The problems facing the respondents in the time of using RADCON and how to solve them according to their view : the Net work doesn't work as usually the computer is breakdown . 
J. Adv. Agric. Res. (Fac. Agric. Saba Basha) 